\title{
The internal structure and composition of a plate-boundary-scale serpentinite shear zone: the Livingstone Fault, New Zealand
}

\author{
Matthew S. Tarling ${ }^{1}$, Steven A. F. Smith ${ }^{1}$, James M. Scott ${ }^{1}$, Jeremy S. Rooney ${ }^{2}$, Cecilia Viti ${ }^{3}$, and Keith C. Gordon ${ }^{2}$ \\ ${ }^{1}$ Department of Geology, University of Otago, 360 Leith Street, 9016 Dunedin, New Zealand \\ ${ }^{2}$ Department of Chemistry, University of Otago, Union Place West, 9016 Dunedin, New Zealand \\ ${ }^{3}$ Dipartimento di Scienze Fisiche, della Terra e dell'Ambiente, Università degli Studi di Siena, Siena, Italy
}

Correspondence: Matthew S. Tarling (tarlingmatthew@gmail.com)

Received: 21 March 2019 - Discussion started: 27 March 2019

Revised: 12 June 2019 - Accepted: 12 June 2019 - Published: 4 July 2019

\begin{abstract}
Deciphering the internal structure and composition of large serpentinite-dominated shear zones will lead to an improved understanding of the rheology of the lithosphere in a range of tectonic settings. The Livingstone Fault in New Zealand is a terrane-bounding structure that separates the basal portions (peridotite; serpentinised peridotite; metagabbros) of the Dun Mountain Ophiolite Belt from the quartzofeldspathic schists of the Caples and Aspiring Terrane. Field and microstructural observations from 11 localities along a strike length of ca. $140 \mathrm{~km}$ show that the Livingstone Fault is a steeply dipping, serpentinite-dominated shear zone tens of metres to several hundred metres wide. The bulk shear zone has a pervasive scaly fabric that wraps around fractured and faulted pods of massive serpentinite, rodingite and partially metasomatised quartzofeldspathic schist up to a few tens of metres long. $\mathrm{S}-\mathrm{C}$ fabrics and lineations in the shear zone consistently indicate a steep east-side-up shear sense, with significant local dispersion in kinematics where the shear zone fabrics wrap around pods. The scaly fabric is dominated ( $>98 \%$ vol) by fine-grained $(\ll 10 \mu \mathrm{m})$ fibrous chrysotile and lizardite-polygonal serpentine, but infrequent $(<1 \%$ vol) lenticular relicts of antigorite are also preserved. Dissolution seams and foliation surfaces enriched in magnetite, as well as the widespread growth of fibrous chrysotile in veins and around porphyroclasts, suggest that bulk shear zone deformation involved pressure-solution. Syn-kinematic metasomatic reactions occurred along all boundaries between serpentinite, schist and rodingite, forming multigenerational networks of nephritic tremolite veins that are interpreted to have caused reaction hardening within metasomatised portions of the shear zone. We propose a concep-
\end{abstract}

tual model for plate-boundary-scale serpentinite shear zones which involves bulk-distributed deformation by pressuresolution creep, accompanied by a range of physical (e.g. faulting in pods and wall rocks; smearing of magnetite along fault surfaces) or chemical (e.g. metasomatism) processes that result in localised brittle deformation within creeping shear zone segments.

\section{Introduction}

The mechanical and seismological properties of serpentinitebearing shear zones are controlled by shear zone structure and composition. Because serpentinite influences the rheology of the lithosphere in a range of tectonic settings, substantial effort has been aimed at collecting experimental (e.g. Reinen et al., 1991, 1994; Moore et al., 1996; Kohli et al., 2011; Auzende et al., 2015; Brantut et al., 2016; Tesei et al., 2018), geochemical (e.g. Viti and Mellini, 1997; Bebout and Barton, 2002) and petrological (e.g. Coleman, 1971; Viti and Mellini, 1998; Auzende et al., 2002) data from serpentine minerals and serpentinite fault rocks. Much of this work has been summarised in a series of recent review papers (Guillot and Hattori, 2013; Hirth and Guillot, 2013; Reynard, 2013; Guillot et al., 2015; Viti et al., 2018). However, extrapolation and upscaling of such data to natural serpentinite shear zones remain problematic because of the following. (1) Serpentinite shear zones are structurally and lithologically complex (Strating and Vissers, 1994; Hermann et al., 2000; Singleton and Cloos, 2012), and their physical properties are therefore not adequately represented by laboratory measurements that 
are often made on small monomineralic samples. (2) Serpentine itself has several subtypes that are challenging to identify unambiguously, particularly in a way that preserves the typically intricate textural relationships between the subtypes. A better understanding of how to apply laboratory data to natural serpentinite shear zones requires improvements to be made on several fronts. This should include effort to document in high resolution the internal structure and composition of well-exposed natural serpentine shear zones across a wide range of scales and metamorphic facies, which will allow interpretations to be made regarding the temporal and spatial evolution of shear zone rheology.

Examples of important serpentinite-bearing shear zones include oceanic detachment faults and fracture zones (Cann et al., 1997; Escartín et al., 2003; Bach et al., 2006), oceanic transform faults (Melson and Thompson, 1971; Skjerlie and Furnes, 1990; Hekinian et al., 1992; Fagereng and MacLeod, 2019) and plate-boundary-scale continental transform faults such as sections of the San Andreas Fault in California, USA (Moore and Rymer, 2007; Moore et al., 2018), and a portion of the southern segment of the Alpine Fault in New Zealand (Barth et al., 2013). Additionally, serpentinitedominated mélanges are associated with ophiolites worldwide (Shackleton et al., 1980; Nicolas et al., 1981; Saleeby, 1984; Norrell et al., 1989; Guillot et al., 2004; Federico et al., 2007; Chen et al., 2014).

While specific processes and microstructures related to serpentinisation and deformation in serpentinite-bearing shear zones have been reported in a wide range of studies (e.g. Maltman, 1978; Williams, 1979; Twiss and Gefell, 1990; Alexander and Harper, 1992; Gates, 1992; Hirauchi and Yamaguchi, 2007; Bellot, 2008; Melosh, 2019; Fagereng and MacLeod, 2019), there are few detailed field descriptions of the internal structure and composition of large serpentinite shear zones (e.g. Norrell et al., 1989; Strating and Vissers, 1994; Hermann et al., 2000; Soda and Takagi, 2010; Singleton and Cloos, 2012). This limits our understanding of the potential role that serpentinite-bearing shear zones may play in controlling processes such as deep episodic tremor and slip (ETS; Poulet et al., 2014), decoupling and weakening of the subducting slab and mantle wedge (e.g. Moore et al., 2004; Moore and Lockner, 2013; Hirauchi et al., 2013), and exhumation of high-pressure metamorphic rocks in subduction channels (Hermann et al., 2000; Federico et al., 2007).

Field-based studies of large serpentinite shear zones typically document a pervasive anastomosing foliation in the bulk of the shear zone (Williams, 1979; Norrell et al., 1989; Strating and Vissers, 1994; Hermann et al., 2000; Soda and Takagi, 2010; Singleton and Cloos, 2012), commonly referred to as "scaly" fabric - a descriptive term used to characterise rocks displaying a phacoidal cleavage at the microscale and macroscale (e.g. Moore, 1986; Vannucchi et al., 2003; Vannucchi, 2019). Some studies have highlighted the potential importance of pressure-solution in the development of this fabric at greenschist-facies conditions (Andréani et al.,
$2004,2005)$. Other studies have focused on the role of metasomatism in areas where serpentinite is in contact with chemically distinct rock types (Moore and Rymer, 2007; Soda and Takagi, 2010). However, field studies are often hampered by relatively limited exposure in areas dominated by scaly serpentinite fault rocks, and it is rare to have the internal structure and composition of a plate-boundary-scale serpentinite shear zone exposed in detail over expansive areas.

The purpose of this paper is to present field and microstructural observations of the internal structure and composition of a plate-boundary-scale serpentinite shear zone that is well exposed in the South Island of New Zealand. The Livingstone Fault represents an important opportunity to document the characteristics of a large serpentinitedominated shear zone from the submicron scale up to the crustal scale. We present structural and petrological data on the geometry, kinematics and composition of the shear zone. These data are used to propose a general conceptual model that could be used as a framework to help interpret the mechanical behaviour and seismological and physical properties of active serpentinite-bearing shear zones.

\section{Geological setting and previous work}

The continent of Zealandia is composed of a series of Cambrian to Cretaceous tectonostratigraphic terranes that were amalgamated on the paleo-Pacific Gondwana margin (Fig. 1). The Zealandia terranes comprise an Early Cretaceous forearc, arc and a portion of the back arc, which were rifted from Australia and Antarctica after ca. $84 \mathrm{Ma}$ (e.g. Gaina et al., 1998). The terranes are broadly subdivided into the Western Province and Eastern Province, which are separated by the Median Batholith (e.g. Landis and Coombs, 1967; Bishop et al., 1985; Mortimer, 2004, Fig. 1). The Western Province is dominated by Early Palaeozoic metasedimentary rocks (e.g. Cooper, 1989; Adams et al., 2015) and was the focus of arc magmatism for $\sim 400 \mathrm{Myr}$ (e.g. Kimbrough et al., 1994; Muir et al., 1996; Tulloch et al., 2009; Allibone et al., 2009). The Eastern Province is dominated by Late Palaeozoic to Mesozoic metasedimentary terranes (e.g. MacKinnon, 1983; Adams et al., 1998) that were progressively accreted above the subduction margin. Sandwiched within the Eastern Province metasedimentary terranes is a Permian-Triassic island arc (Brook Street Terrane; Landis et al., 1999, Fig. 1) and an ophiolite belt (Dun MountainMaitai Terrane, referred to commonly as the Dun Mountain Ophiolite Belt, DMOB; Fig. 1; Coombs et al., 1976, Fig. 1). The Cretaceous boundary between the Western Province and Eastern Province is a complex zone of arc magmatism that intrudes both provinces and is referred to as the Median Batholith (Mortimer et al., 1999). A series of major ductile shear zones mark a precise Western Province-Eastern Province boundary in some places (Bradshaw, 1993; Allibone and Tulloch, 2008; Scott, 2013). Most terrane bound- 

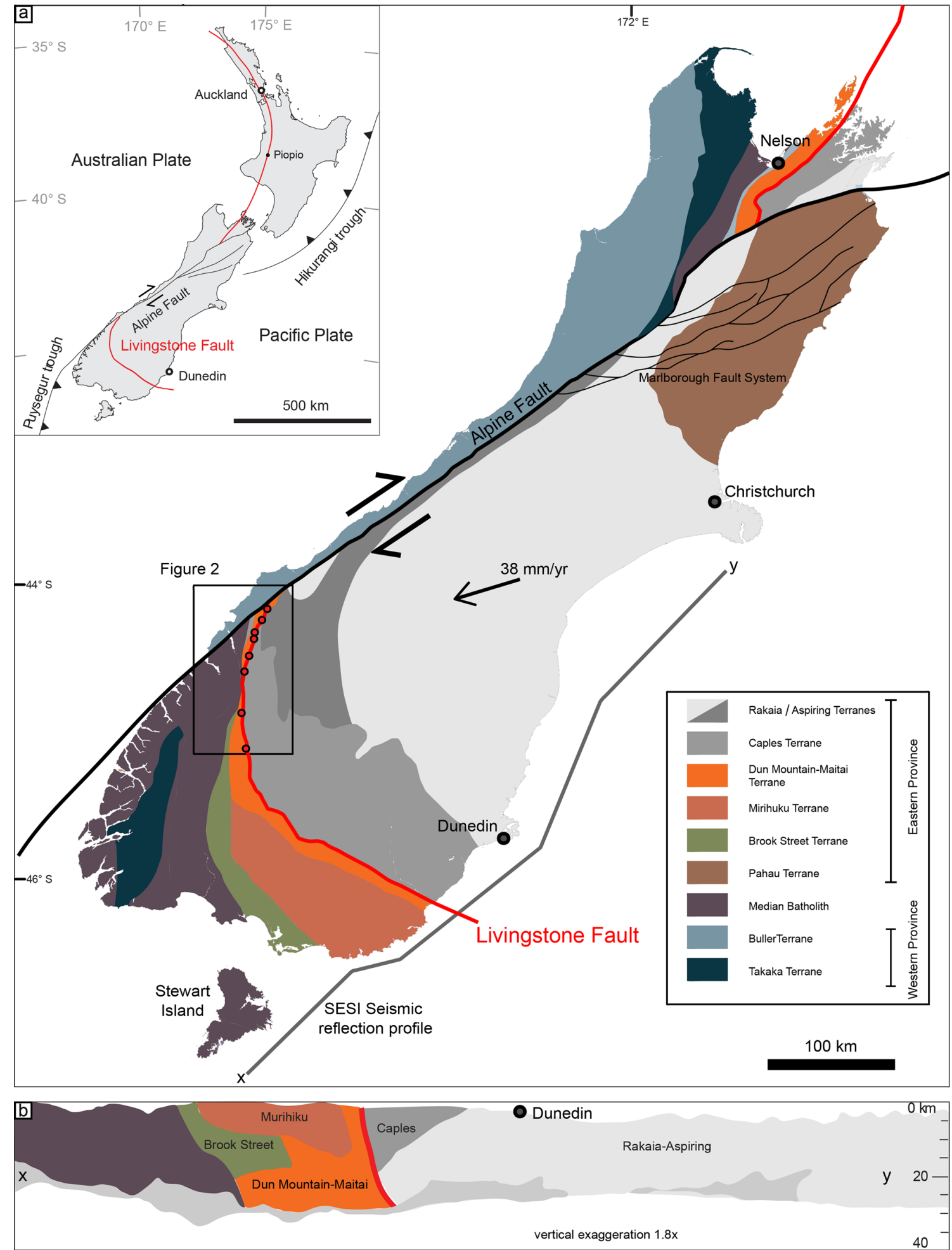

Figure 1. Regional geological setting. (a) Simplified regional map of the basement geology and tectonic setting of the South Island of New Zealand. Inset shows a map of New Zealand with present-day plate boundaries and the location of the Livingstone Fault in the North and South Island. Piopio (inset map) is the only exposure of the Dun Mountain Ophiolite Belt in the North Island of New Zealand (O'Brien and Rodgers, 1973). Modified from Cooper and Ireland (2015) with data from Mortimer (2004). (b) The regional-scale cross section along line $x-y$ (shown in panel a) is based on an interpretation of the composite southeast South Island (SESI) seismic reflection profile by Mortimer et al. (2002). 
aries, however, appear to have been reactivated by Cenozoic faulting associated with the development of the present-day Australia-Pacific plate boundary system.

The Livingstone Fault is the terrane boundary that defines the eastern margin of the DMOB (Figs. 1, 2). The DMOB is a narrow slice $(<20 \mathrm{~km})$ of Permian oceanic lithosphere that can be traced for more than $1000 \mathrm{~km}$ through the North and South Island of New Zealand, although it has been offset by $480 \mathrm{~km}$ across the Alpine Fault in the last ca. $25 \mathrm{Myr}$ (Wellman, 1953; Sutherland et al., 2000). The DMOB is well exposed in the South Island of New Zealand. In the North Island it is buried underneath relatively young volcanic and sedimentary rocks, except in one location at Piopio (Fig. 1). However, it can be traced through the North Island using the strong positive magnetic anomaly that is formed by magnetite-bearing serpentinites (Coombs et al., 1976; Eccles et al., 2005). A complete ophiolite sequence that includes an ultramafic basal section (harzburgite to dunite and serpentinised equivalents), a mafic dyke complex, a mafic volcanic sequence and an overlying sedimentary sequence (the Maitai sequence, including limestones, conglomerates, sandstones, mudstones, volcaniclastics) is preserved at Red Mountain in South Westland (Fig. 2) and at Dun Mountain near Nelson (Coombs et al., 1976; Sinton, 1977; Sano et al., 1997; Stewart et al., 2016). The ophiolite sequence was rotated so that the bulk layering is now sub-vertical and the overall sequence youngs from east to west (Fig. 2; Eccles et al., 2005; Gray et al., 2007). Uranium- $\mathrm{Pb}$ zircon dates from plagiogranites in the upper portion of the layered gabbros and dike complex suggest a formation age of 275-285 Ma (Kimbrough et al., 1992), which is consistent with detrital zircons in the sedimentary Maitai component (Jugum et al., 2013). The DMOB is situated between zeolite facies volcanogenic sediments of the Murihiku Terrane to the west and prehnite-pumpellyite to lower greenschist-facies schists of the Caples Terrane and Aspiring Terrane to the east (Figs. 1, 2).

The DMOB and Livingstone Fault are well exposed in intermittent locations through a $\sim 150 \mathrm{~km}$ long strip in the South Westland area of the Southern Alps, which is the focus of this paper (Figs. 1, 2). Early work mentioning the Livingstone Fault consisted mainly of regional mapping projects focused on the adjacent Murihiku and Caples-Aspiring Terrane (Hutton, 1936; MacPherson, 1946; Wood, 1956; Grindley, 1958; Coombs et al., 1976; Bishop et al., 1976; Craw, 1979; Turnbull, 1980; Cawood, 1986, 1987). Grindley (1958) and Bishop et al. (1976) noted that the fault has a steeply eastdipping or sub-vertical orientation. The most comprehensive work to date was by Craw (1979), who recognised the fault to be a sub-vertical to steeply east-dipping serpentinitebearing shear zone up to $200 \mathrm{~m}$ wide near West Burn (Fig. 2). Later work by Cawood $(1986,1987)$ in the central Southland area recognised a steeply dipping fault characterised in places by a schistose serpentinite matrix containing blocks of quartzofeldspathic lithologies, massive serpentinite and rodingite (metagabbro and metadolerite) up to $5 \mathrm{~m}$ long. In- terpretations of the southeast South Island (SESI) geophysical transect suggest that the Livingstone Fault probably extends at least to the base of the crust at $20-30 \mathrm{~km}$ of depth (Fig. 1b) (Mortimer et al., 2002). Cawood (1986) interpreted the most recent phase of deformation as involving a steep reverse sense of motion, with the Caples and Aspiring Terrane having been thrust over the DMOB. However, the timing of deformation events is poorly constrained because the shear zone assemblages are not conducive to dating. It seems likely that the Livingstone Fault has experienced multiple phases of reactivation, including possible Cenozoic reactivation where it lies subparallel to the Alpine Fault. The fault must have been active post-Jurassic because these are the youngest sedimentary strata found in the adjacent terranes (Cawood, 1986).

\section{Methods}

\subsection{Fieldwork and drone-assisted mapping}

Detailed field mapping, sampling and structural data collection were performed at 12 locations along a strike length of ca. $140 \mathrm{~km}$ (Fig. 2). Around $5 \mathrm{~km}$ to the NE of Cosy Gully, the Livingstone Fault is truncated by the Alpine Fault. In several locations (stereonets in Fig. 2), the asymmetry of welldefined $\mathrm{S}-\mathrm{C}$ fabrics, combined with lineation measurements, allowed the bulk shear sense to be determined. Orientated samples were collected that represent the main shear zone, wall rock and metasomatic lithologies, and the most important macroscale structural characteristics of the shear zone were noted.

Drone imagery and photogrammetry were used to produce a high-resolution orthorectified aerial photo of the Livingstone Fault at Serpentine Saddle (Fig. 2), which was used as a base map to survey the internal structure of the shear zone at this locality. Aerial photography was performed using a DJI Phantom 4 Pro drone (DJI; Shenzhen, China), which was manually piloted at an average height of approximately $55 \mathrm{~m}$ above ground level. GPS-tagged pictures were taken at a semi-regular interval in order to obtain approximately $30 \%$ lateral and $60 \%$ forward overlap between adjacent photos. A total of 615 pictures were taken, covering a total area of approximately $0.3 \mathrm{~km}^{2}$. The photographs were processed using Agisoft PhotoScan software to create a single orthorectified aerial photo with a ground resolution of ca. $2.15 \mathrm{~cm}$ per pixel. Image analysis with ImageJ software (Schneider et al., 2012) was used to quantify the abundance of shear zone lithologies after mapping had been completed.

\subsection{Microscopy and microstructural observations}

Thin sections of fault rocks were cut parallel to lineation and perpendicular to foliation. Standard $30 \mu \mathrm{m}$ thick polished petrographic thin sections were prepared for microstructural observations. Observations were carried out using a combi- 


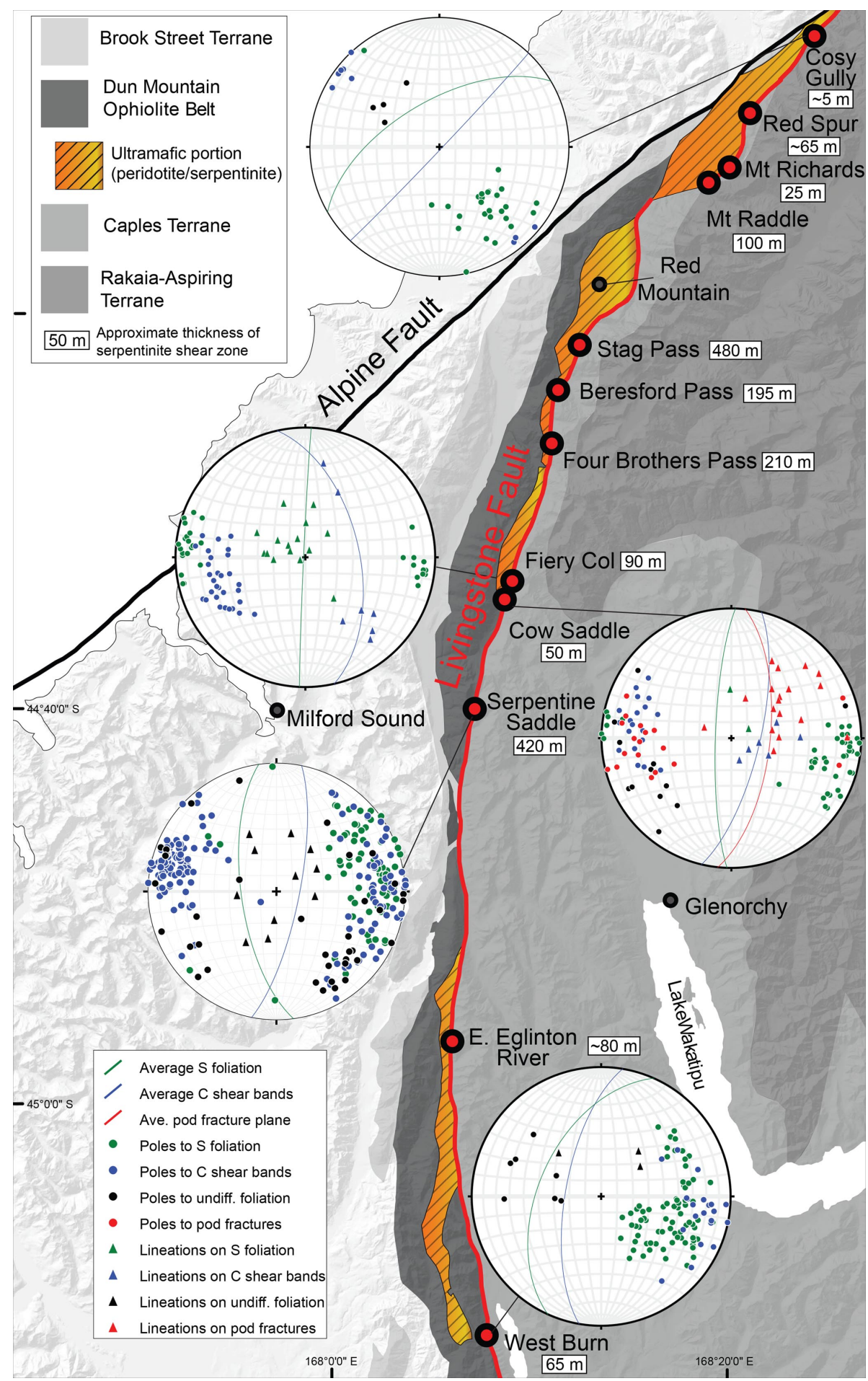

Figure 2. Simplified geological map of the Livingstone Fault with 11 study sites marked, from Cosy Gully in the north to West Burn in the south. The approximate thickness of the serpentinite shear zone based on field observations is shown at each locality. Stereonets (all lower hemisphere, equal area) represent measurements of the main shear zone fabrics, including undifferentiated scaly foliations, S-C fabrics where present and lineations. At Cow Saddle, additional data are provided for the orientations of brittle faults and associated lineations that cut through pods of massive serpentinite. Stereonets produced using Stereonet v10.1.6 (Allmendinger et al., 2011). 
nation of transmitted and reflected-light optical microscopy, Raman spectroscopy mapping (Sect. 3.3), scanning electron microscopy (SEM) and transmission electron microscopy (TEM). SEM imaging was performed using a Zeiss Sigma VP field-emission scanning electron microscope at the Otago Centre for Electron Microscopy. The SEM was conducted using an accelerating voltage of $15 \mathrm{kV}$ and a working distance ranging from 6 to $8.5 \mathrm{~mm}$. TEM samples were extracted from thin sections prepared using Canada balsam adhesive by mounting copper annuli grids $3 \mathrm{~mm}$ in diameter with a central hole of $800 \mu \mathrm{m}$ diameter. $\mathrm{An}^{+}{ }^{+}$precision ion polishing system (PIPS) was used to mill the samples to electron transparency (Gatan Inc., United States). TEM analysis was performed on a JEOL JEM-2010 microscope (JEOL Ltd., Tokyo, Japan) at the University of Siena, Italy. The TEM was conducted at $200 \mathrm{kV}$ with a LaB6 source and ultra-high-resolution pole pieces, resulting in a point resolution of $0.19 \mathrm{~nm}$.

\subsection{Raman spectroscopy}

Thin sections prepared for Raman spectroscopy were glued using a low-fluorescence epoxy (Epofix cold-setting embedding resin, Struers) (Rooney et al., 2018). Raman spectroscopy mapping was performed on an Alpha 300R+ confocal Raman microscope (WITec GmbH, Ulm, Germany) in the Chemistry Department at the University of Otago, New Zealand. A dry 100× objective (Carl Zeiss AG, Oberkochen, Germany), $1200 \mathrm{~g} \mathrm{~mm}^{-1}$ grating and a $532 \mathrm{~nm}$ wavelength laser (Coherent, Santa Clara, California) at ca. $50 \mathrm{~mW}$ were used. The laser spot size and spatial resolution of this setup is approximately $370 \mathrm{~nm}$ (Rooney et al., 2018). A piezo-controlled nanopositioning stage was used to control the sample position during the Raman mapping process. The Raman microscopy system was calibrated with a semiconductor-grade silicon wafer using the $520.6 \mathrm{~cm}^{-1}$ band, followed by verification of the $3620.6 \mathrm{~cm}^{-1}$ band from a sample of kaolinite. WITec Project Plus software was used to analyse the Raman data to produce colour maps based on the spatial distribution of the Raman signal of the minerals present. Full details regarding the collection and processing of submicron Raman spectroscopy data are available in Rooney et al. (2018) and Tarling et al. (2018a).

\section{Results}

\subsection{Regional structure and kinematics of the Livingstone Fault}

The Livingstone Fault consists of a serpentinite-dominated shear zone that separates the mainly quartzofeldspathic schists of the Caples and Aspiring Terrane from mafic or ultramafic portions of the DMOB (Fig. 3). In many of the examined localities (i.e. Fiery Col, Cow Saddle, Mount Raddle, Mount Richards, Red Spur), the DMOB wall rocks are

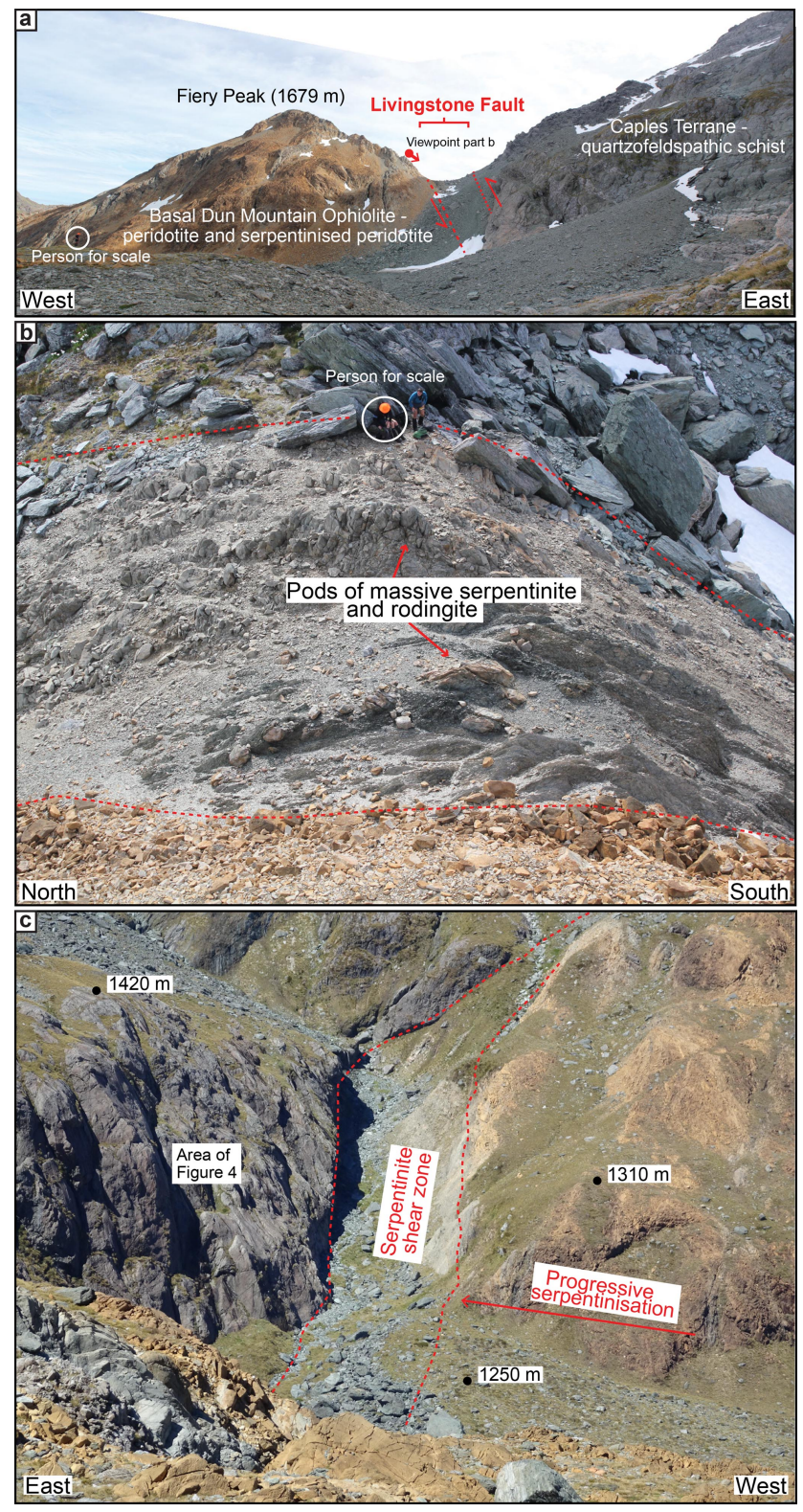

Figure 3. Typical field exposures of the Livingstone Fault where it crosses high passes. Red dashed lines approximate the boundaries of the serpentinite shear zone. (a) Panorama of Fiery Col viewed from the south. Person for scale circled in white. Here, the shear zone separates massive serpentinite and serpentinised peridotite from schists of the Caples-Aspiring Terrane. (b) Fiery Col viewed from below Fiery Peak (location shown in panel a). Elongate pods of massive serpentinite are surrounded by scaly serpentinite. The boundaries between the serpentinite shear zone and the wall rocks are well defined. (c) Cow Saddle viewed from the north. The DMOB wall rocks are progressively serpentinised towards the western boundary of the shear zone. The area shown in Fig. 4 is also indicated. 
peridotite and serpentinised peridotite (Fig. 2). However, at Serpentine Saddle (Sect. 4.2), Four Brothers Pass and Beresford Pass, ultramafic portions of the ophiolite are absent and the serpentinite shear zone separates Caples-Aspiring schists from DMOB metagabbros and associated dykes. The thickness of the shear zone varies significantly along strike (Fig. 2). For example, at Fiery Col (Fig. 3a, b) and Cow Saddle (Fig. 3c), the shear zone is $50-90 \mathrm{~m}$ wide (similar to West Burn, east Eglinton River, Mount Raddle and Red Spur; Fig. 2). At Serpentine Saddle the shear zone is up to $420 \mathrm{~m}$ wide and at Stag Pass it is $480 \mathrm{~m}$ wide, whereas at Mount Richards $(25 \mathrm{~m})$ and Cosy Gully $(5 \mathrm{~m})$ it is much narrower.

Boundaries between the serpentinite shear zone and the wall rocks are commonly steeply dipping and well defined (Fig. 3). In locations where the DMOB wall rocks are peridotite or serpentinised peridotite, the western boundary of the shear zone is defined by a progressive transition, over a distance of a few metres to tens of metres, from scaly shear zone serpentinite to partially serpentinised peridotite and then into peridotite (Fig. 3c). At Serpentine Saddle, where the DMOB wall rocks are metagabbros, late-stage faults offset and disrupt the western shear zone boundary. The eastern shear zone boundary is typically defined by a network of steeply dipping brittle faults within and at the contact with the schist host rocks (Figs. 3c, 4). These faults surround lenses of partially metasomatised and fractured schist up to hundreds of metres long and tens of metres wide (Fig. 4a). The faults have polished, slickensided surfaces (Fig. 4b) associated with wellcemented cataclasite layers up to $2 \mathrm{~cm}$ thick. The faults are mainly sub-vertical to steeply west dipping, and lineations plunge sub-vertically (Fig. 4b).

All exposures of the serpentinite shear zone are characterised by a strongly foliated matrix with a scaly fabric, defined by sub-centimetre asymmetric phacoids of serpentinite (Fig. 5). This fabric wraps around pods of rodingite, quartzofeldspathic schist, massive serpentinite and veined serpentinite ranging from centimetres to tens of metres long (Figs. 3b, 5, 7). The surfaces of serpentinite phacoids are often polished and contain lineations defined by surface striae (i.e. grooves) or bundles of aligned serpentine mineral fibres. Overall, the scaly foliation is steeply dipping and subparallel to the regional orientation of the Livingstone Fault (Fig. 2). In several localities (green and blue data on stereonets in Fig. 2), the scaly foliation is represented by a well-defined S-C fabric (Figs. 2, 5; Berthé et al., 1979; Lister and Snoke, 1984; Passchier and Trouw, 2005). The intersections between the "S" foliation surfaces and the "C" shear bands plunge shallowly in a direction subparallel to the strike of the shear zone boundaries (Fig. 2). The $\mathrm{C}$ shear bands are relatively planar, continuous for up to tens of centimetres and deflect the $S$ fabric (Fig. 5). There is an angle of $25-40^{\circ}$ between the $\mathrm{S}$ and $\mathrm{C}$ surfaces (Fig. 2). Both the internal and external asymmetry of the S-C fabric (as defined in Passchier and Trouw, 2005; Fig. 5), combined with the dominance of moderately to steeply plunging shear zone lineations (Fig. 2), consistently indicate an overall Caples-Aspiring-Terrane-up shear sense (i.e. east-side up).

At Cow Saddle, pods of massive serpentinite are cut by en echelon brittle faults that have a similar orientation to the $\mathrm{C}$ shear bands in the surrounding matrix (Figs. 2, 5). These faults contain steeply plunging lineations (Fig. 2) and show offsets that are compatible with the overall east-side-up kinematics inferred from the $\mathrm{S}-\mathrm{C}$ fabrics (Figs. 2, 5). Additionally, at Cow Saddle and Fiery Col, much larger pods of schist up to $200 \mathrm{~m}$ long and up to $60 \mathrm{~m}$ wide are completely surrounded by serpentinite, indicating that they were probably fault-bound lenses of Caples-Aspiring Terrane (such as those shown in Fig. 4a) that were plucked off and incorporated into the serpentinite shear zone.

The Livingstone Fault contains metasomatic reaction zones in a number of structural locations, and the reaction zones are ubiquitous at all the investigated localities shown in Fig. 2. The main chemical reactions that occurred in the Livingstone Fault will be described elsewhere and only a brief description of the most important characteristics is provided here. Along the main shear zone boundary that separates serpentinite from the Caples-Aspiring Terrane schists, metasomatic reaction zones are characterised by multigenerational tremolite (and minor talc and diopside) vein networks that form within tabular layers up to several tens of metres wide (Fig. 6). Metasomatic hydrogrossular, andradite garnet and clinochlore are found as accessory minerals both within the veins and in the adjacent serpentinite. Additionally, pods of schist, rodingite and partially rodingitised gabbro-dolerite within the shear zone can be surrounded by complex tremolite vein networks up to several metres wide (Fig. 6a). Overall, the metasomatic veins lack any strong preferred orientation, although in some places the earliest vein set appears to have exploited the serpentinite foliation. Many of the veins appear to be mainly tensile in nature, with little apparent shear offset. Where cross-cutting of pre-existing veins can be seen, some proportion of the later veins show apparent shear offset (up to centimetre scale), providing evidence for a shear component in vein formation. However, the complex and inherently three-dimensional nature of the multigenerational vein networks makes the proportion of tensile and shear veins difficult to assess without a more detailed analysis. In areas of the shear zone that are severely metasomatised, the vein networks and surrounding serpentinite are cut by discrete, cataclastic fault surfaces that are steeply dipping and contain steeply plunging lineations (Fig. 6b), consistent with the kinematics determined from the scaly foliation and from fault surfaces that cut through pods. 

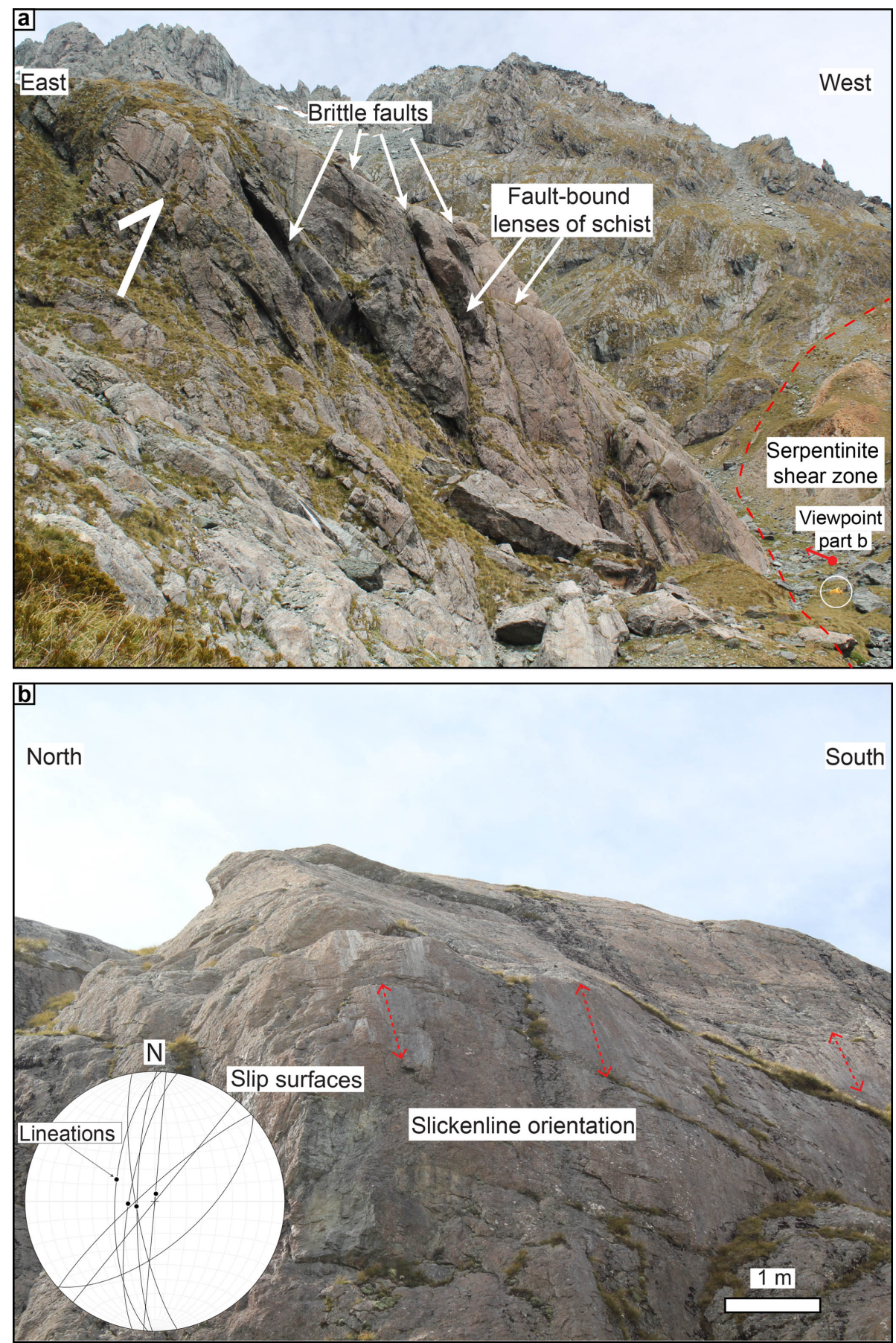

Figure 4. Deformation in the Caples-Aspiring Terrane wall rocks at Fiery Col and Cow Saddle. (a) Photo looking south from Fiery Col towards Cow Saddle (location shown in Fig. 3c). Schists adjacent to the eastern boundary of the serpentinite shear zone are cut by linked arrays of brittle faults that surround large lenses of metasomatised and fractured schist. Tent for scale circled in white. (b) The brittle faults are characterised by polished slickensides with lineations and cataclastic slip zones. The stereonet (lower hemisphere, equal area) shows the orientations of eight fault surfaces with associated steeply plunging lineations. 


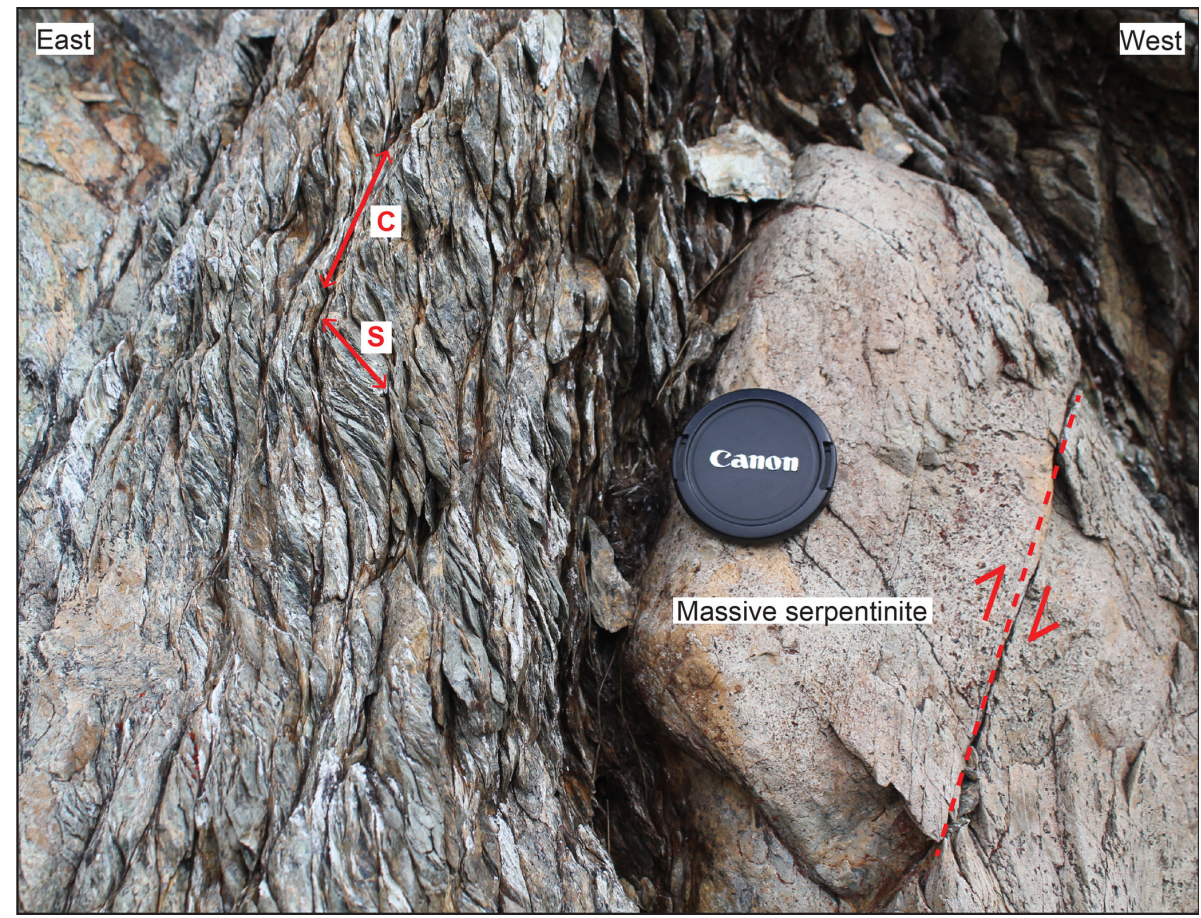

Figure 5. Photo showing well-defined $\mathrm{S}-\mathrm{C}$ fabrics at Cow Saddle, wrapping around a fractured pod of massive serpentinite. Structural data from Cow Saddle are shown in Fig. 2. The asymmetry of the $\mathrm{S}-\mathrm{C}$ fabric, combined with moderately to steeply plunging lineations on foliation surfaces and shear bands, suggests an east-side-up (i.e. Caples-Aspiring-side-up) shear sense. Fractures that cut through pods of massive serpentinite at this locality are subparallel to the $\mathrm{C}$ shear bands in the surrounding scaly matrix and have small offsets consistent with an east-side-up shear sense.
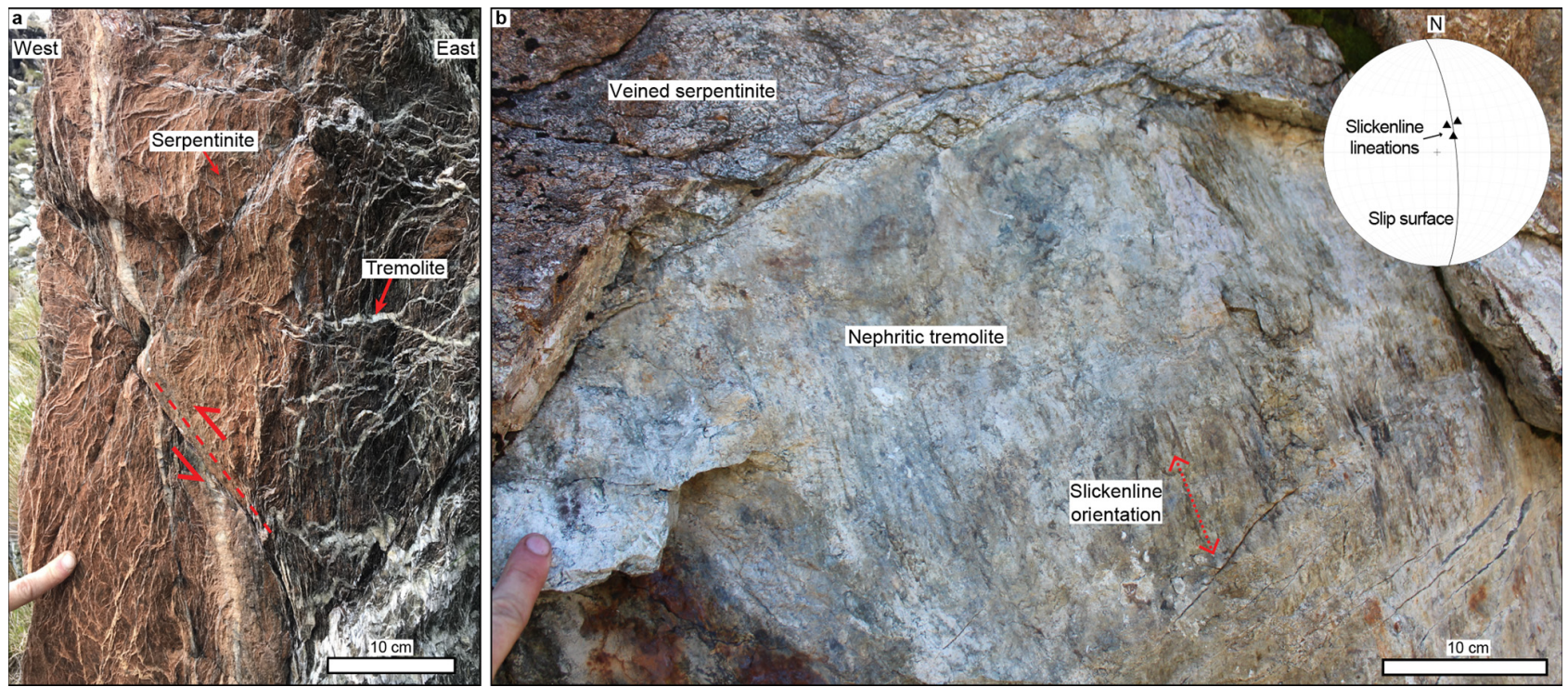

Figure 6. Tremolite vein networks and associated discrete slip surfaces. (a) Multigenerational tremolite vein network at the contact between serpentinite and Caples-Aspiring Terrane schist at Beresford Pass. Cross-cutting fault noted in red. (b) A discrete slip surface cross-cutting the metasomatic reaction zone between serpentinite and Caples-Aspiring Terrane schist at Fiery Col displays steeply plunging slickenlines consistent with overall fault kinematics. 


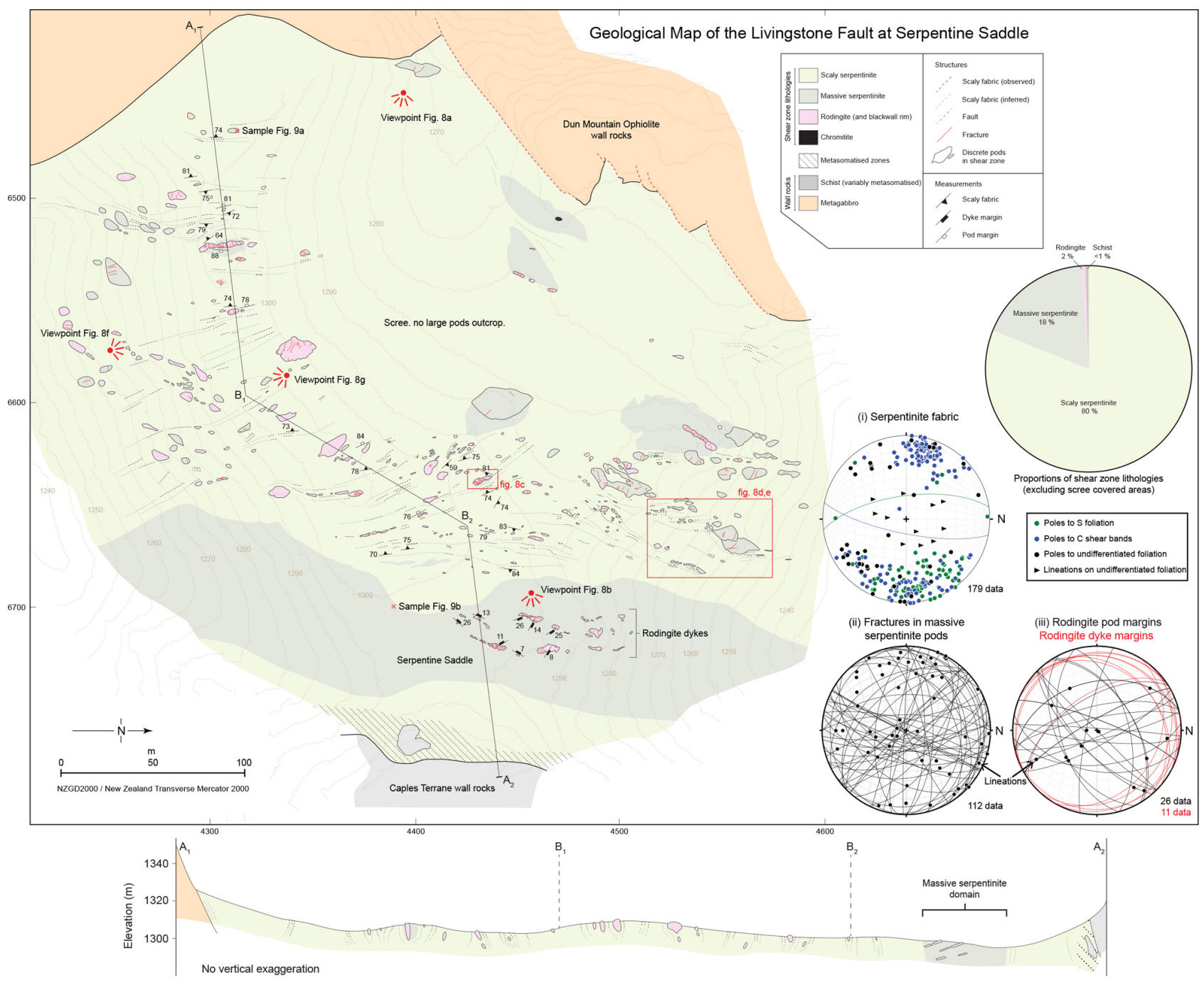

Figure 7. Detailed geological map and cross section of the Livingstone Fault at Serpentine Saddle derived from field mapping onto highresolution, drone-acquired orthophotos. The map highlights the internal structure and composition of the serpentinite shear zone at this locality, including the traces of the scaly fabrics, pods of rodingite and massive serpentinite, and larger domains of massive serpentinite containing gently dipping rodingite dykes. The locations of images shown in Fig. 8, and some samples shown in Fig. 9, are also indicated. Stereonets (lower hemisphere, equal area) show measurements of (i) S-C fabrics, undifferentiated scaly foliation, lineations in the shear zone, (ii) brittle faults and associated lineations that cut through massive serpentinite pods, (iii) the margins of rodingite dykes and pods, and lineations on slickensided margins of pods. The pie chart shows the abundance of the most important lithologies within the shear zone in the mapped area (wall rocks are excluded). Light brown lines are topographic contours at $5 \mathrm{~m}$ intervals.

\subsection{Internal structure and composition of the Livingstone Fault at Serpentine Saddle}

\subsubsection{Overall shear zone structure and wall rocks}

The shear zone at Serpentine Saddle is up to $420 \mathrm{~m}$ thick (Figs. 7, 8a). The DMOB wall rocks here consist mainly of metagabbros and associated dykes; no wall rock peridotite or serpentinised peridotite is present in this locality. The Caples-Aspiring Terrane wall rocks on the eastern side are dominated by greenschist-facies metamorphic assemblages containing quartz, plagioclase, chlorite, epidote and mus- covite (Bishop et al., 1976; Turnbull, 1980). The western boundary of the shear zone is irregular due to the presence of late-stage brittle fault surfaces that offset the boundary between the shear zone and the basal DMOB wall rocks (Fig. 7). The eastern shear zone boundary is defined by a region up to $20 \mathrm{~m}$ wide containing extensively metasomatised Caples-Aspiring Terrane schists, as well as networks of metasomatic veins.

The shear zone in the mapped area consists of the following (Fig. 7): 

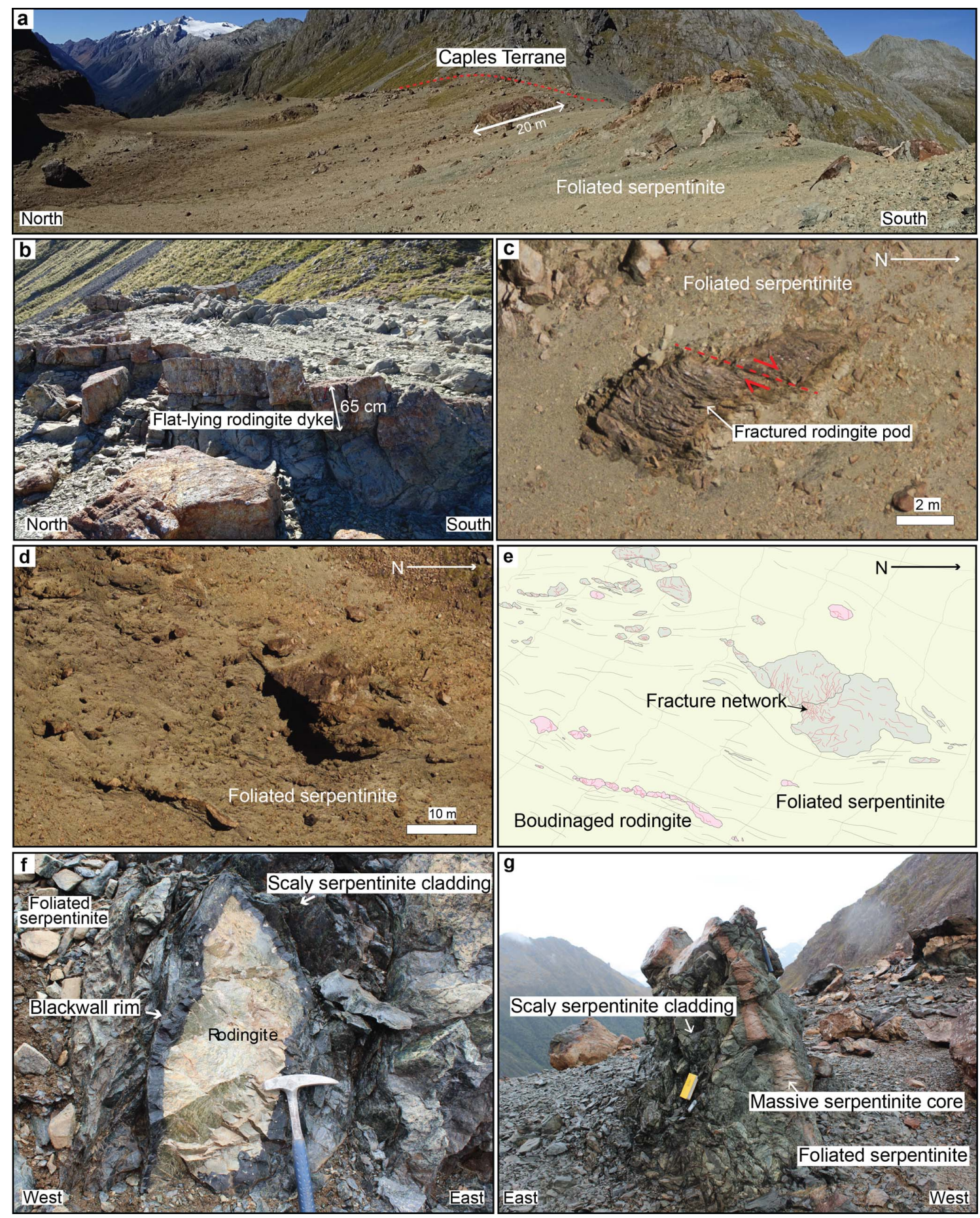

Figure 8. Shear zone structures at Serpentine Saddle. Location of the images shown on the map in Fig. 7. (a) Panorama of Serpentine Saddle looking east towards the Caples-Aspiring Terrane wall rocks. Upstanding spines on the ridgeline are elongate pods of massive serpentinite and rodingite. (b) Gently dipping rodingite dykes in a large massive serpentinite domain. (c) High-resolution orthophoto showing an intensely fractured and boudinaged rodingite pod surrounded by scaly serpentinite. (d) High-resolution orthophoto and (e) corresponding line tracing showing a boudinaged rodingite dyke (bottom left in both figures) and two large pods of massive serpentinite that have been brought into contact. A dense network of fractures radiates outwards from the contact region between the two pods of serpentinite. (f) Rodingite pod enclosed by a blackwall rim and surrounding matrix of scaly serpentinite. (g) Serpentinite pod with a massive serpentinite core and a cladding that transitions to scaly serpentinite. 
1. $\sim 80 \%$ scaly serpentinite that in places has a welldefined S-C fabric (stereonet i);

2. $\sim 18 \%$ massive serpentinite, which occurs either as fractured and boudinaged pods up to ca. $20 \mathrm{~m}$ long (stereonet ii) or in much larger domains that have gradational boundaries with the surrounding scaly serpentinite;

3. $\sim 2 \%$ rodingite, which occurs either as fractured and boudinaged pods up to $30 \mathrm{~m}$ long or as relatively planar, shallowly dipping dykes within massive serpentinite domains (stereonet iii);

4. $<1 \%$ schist, which is mainly represented by a single pod close to the eastern shear zone boundary; and

5. $<0.01 \%$ chromitite pods up to a few metres in size that are dispersed throughout the shear zone and are typically bound by highly polished cataclastic fault surfaces.

\subsubsection{Massive serpentinite domains and pods in the shear zone}

Large domains of massive serpentinite tens to hundreds of metres long (Fig. 7) are characterised by a negligible to weak fabric, as well as preservation of mesh-textured serpentinite (Sect. 4.3). Sub-horizontal to shallowly dipping rodingite dykes are preserved in these domains (Figs. 7, 8b). Outside the massive serpentinite domains, the rodingite dykes are progressively rotated into alignment with the steeply dipping scaly foliation, resulting in fracturing and boudinage of the dykes to form isolated pods surrounded by serpentinite (Figs. 7, 8c) or chains of aligned elongate pods (Figs. 7, $8 \mathrm{~d}, \mathrm{e})$. The margins of some rodingite pods are sheathed in a metasomatic "blackwall" rim consisting mainly of monomineralic fine-grained chlorite (Fig. 8f). In places, the blackwall rim is sheared off or disrupted by the scaly fabric, putting the rodingite in direct contact with the scaly serpentinite. In these cases, networks of nephritic tremolite veins are found along the contacts between rodingite and serpentinite. The outer margins of the rodingite pods are commonly defined by polished slickensides containing shallowly to steeply plunging lineations (stereonet iii, Fig. 7), with underlying cataclastic layers up to tens of centimetres thick. In detail, the margins of rodingite (and massive serpentinite) pods show two preferred orientations: (1) NW-SE striking and steeply NE or SW dipping; and (2) E-W striking and moderately to steeply $\mathrm{N}$ or $\mathrm{S}$ dipping (stereonet iii, Fig. 7). These preferred orientations highlight the characteristic shape of many of the pods: in map view, pods often have a lenticular to rhomboidal shape, with the long axis of the pod (in map view) subparallel to the strike of the surrounding scaly foliation and the margins of the shear zone. Although outcrop constraints limited the investigation of shear zone geometry in cross-sectional view, pods that could be observed in three dimensions also showed a slightly asymmetric lenticular or rhomboidal shape in cross section (Fig. 8f). The asymmetry of the pods in cross section is compatible with the Caples-Aspiring-Terrane-up (east-side-up) shear sense indicated by the $\mathrm{S}-\mathrm{C}$ fabrics in the scaly serpentinite.

Pods of serpentinite contain a central core of massive serpentinite surrounded by an outer cladding that transitions towards scaly serpentinite (Fig. 8g). The massive serpentinite pods are typically heavily fractured with a range of fault and lineation orientations (stereonet ii, Fig. 7). In one area of the map, two large pods of massive serpentinite are observed to be in direct contact with one another, interpreted to result from "collision" between the two pods during shearing (Figs. 7, 8d, e). In this location, the contact zone between the two pods contains a dense network of fractures that radiate outwards from the area of contact into the centre of the pods (Fig. 8d, e).

Another type of resistant pod observed in the shear zone consists of moderately foliated serpentinite containing embedded fragments of partially rodingitised gabbroic to doleritic dykes (up to tens of centimetres wide by tens of centimetres to metres in length). Networks of tremolite veins radiate out from the dyke fragments and cross-cut the surrounding serpentinite foliation.

\subsubsection{Scaly foliation and S-C fabrics}

The S-C fabrics and associated lineations at Serpentine Saddle indicate an overall Caples-Aspiring-Terrane-up shear sense (east-side up), consistent with other localities (Figs. 2, 7). However, in detail there is substantial spread in the orientations of the scaly foliation, $\mathrm{S}-\mathrm{C}$ fabrics and lineations due to deflection around pods and massive serpentinite domains (stereonet i in Fig. 7) (Vannucchi et al., 2003; Vannucchi, 2019). The mean orientation of the $S$ fabric is $172 / 68^{\circ} \mathrm{W}$, with $80^{\circ}$ of strike dispersion and $40^{\circ}$ of dip dispersion exhibited by the main cluster of data points (stereonet $\mathrm{i}$ in Fig. 7). The mean orientation of the $\mathrm{C}$ shear bands is $014 / 79^{\circ} \mathrm{E}$, with $90^{\circ}$ of strike dispersion and $35^{\circ}$ of dip dispersion (stereonet $\mathrm{i}$ in Fig. 7).

\subsection{Composition and textural evolution of the serpentinite shear zone}

\subsubsection{Massive serpentinite domains and pods}

Massive serpentinite within pods contains relatively undeformed pseudomorphic bastite and mesh textures, suggesting that these regions represent largely intact serpentinised peridotite (Viti and Mellini, 1998) (Fig. 9a). Bastites are textural pseudomorphs of pyroxene minerals, while mesh-textured serpentine forms as the result of the serpentinisation of olivine grains (Viti and Mellini, 1998; Wicks and Whittaker, 1977). Raman spectroscopy reveals that the massive serpentinite is primarily composed of lizardite, chrysotile and mag- 
netite. Serpentinisation of the original olivine and pyroxene typically produces abundant magnetite that is initially disseminated throughout the pseudomorphic serpentinite as submicron grains (Figs. 9, 10; O’Hanley and Dyar, 1993). Around the edges of massive serpentinite pods and domains, pseudomorphic serpentinite shows textural evidence for the onset of shearing (Fig. 9b). The mesh textures show signs of developing into "ribbon-textured" serpentinite, whereby portions of the mesh structure are preferentially dissolved to form elongate lensoid ribbons (Fig. 9b) (Viti et al., 2018). In such areas, porphyroclastic magnetite (Fig. 9b) and relict chromite grains are also common. Partial dissolution of the mesh-textured serpentinite results in some initial concentration of magnetite around the boundaries of the deforming meshes. Magnetite-rich seams are continuous along these boundaries for at least several millimetres (Fig. 9b).

\subsubsection{Scaly shear zone serpentinite}

The most common scaly serpentinite in the shear zone consists of phacoids of serpentinite that have rounded edges and sigmoidal shapes that contribute to the asymmetry of the S$\mathrm{C}$ fabric (Fig. 5). The slip surfaces that make up the exterior of these lenses are commonly coated in a shiny, polished serpentinite, although in some outcrops weathered coatings of fibrous chrysotile give the serpentinite a rougher, splintery appearance. The scaly serpentinite displays a "fractal-like" geometry in which each phacoid can be cleaved apart to create smaller phacoids of serpentinite, a common characteristic of scaly fabric fault rocks (Maltman et al., 1997; Vannucchi et al., 2003; Vannucchi, 2019; Melosh, 2019). This self-similarity in geometry is observed down to a scale of $<10 \mu \mathrm{m}$, at which lenticular domains of serpentinite are separated by shear planes along which seams of magnetite are concentrated (Fig. 10).

The shape of individual phacoids and the spacing of the foliation surfaces can vary substantially throughout the shear zone. In samples of scaly serpentinite that have relatively widely spaced foliation surfaces, deformed mesh and ribbon-textured serpentinite are preserved inside phacoids, and the phacoids are coated by continuous and interconnected seams of magnetite (Fig. 10a). Where the foliation surfaces are more closely spaced, phacoids of serpentinite contain no evidence for the preservation of pseudomorphic textures (Fig. 10b). Instead, lenticular domains of fine-grained chrysotile, lizardite and/or polygonal serpentine are outlined by interconnected seems of magnetite and fibrous chrysotile (Fig. 10b). In scaly serpentinite with lower proportions of magnetite, discontinuous seams of magnetite are concentrated along the boundaries of the scaly foliation, broadly defining the overall lenticular shape of serpentinite phacoids (Fig. 10c).

A combination of TEM and Raman spectroscopy mapping reveals that the scaly serpentinite is composed of fibrous chrysotile (70 wt \%-80 wt \%; Fig. 11a, b, c), lizardite
(10 wt \%-25 wt \%; Fig. 11b, d), minor polygonal serpentine (Fig. 11c) and magnetite (Tarling et al., 2018a; Rooney et al., 2018). Relict chromite grains are dispersed throughout the serpentinite and are typically mantled by a layer of ferritchromit and occasionally surrounded by chloritic aureoles, which are thought to form by a dissolution-precipitation mechanism (Mellini et al., 2005). Minor brucite occurs in association with sheared lizardite and chrysotile. Secondary phases dispersed as small grains (tens of microns in size up to the millimetre scale) throughout the scaly serpentinite include awaruite $\left(\mathrm{Ni}_{2-3} \mathrm{Fe}\right)$, wairauite $(\mathrm{CoFe})$, pentlandite $\left((\mathrm{Fe}, \mathrm{Ni})_{9} \mathrm{~S}_{8}\right)$, millerite $(\mathrm{NiS})$, heazlewoodite $\left(\mathrm{Ni}_{3} \mathrm{~S}_{2}\right)$, native copper and copper oxides.

Aggregates of antigorite are present within small (10$400 \mu \mathrm{m}$ ), isolated porphyroclasts distributed throughout the scaly serpentinite but make up $<1 \%$ vol (Fig. 11a, b). The porphyroclasts consist of interpenetrating blades of antigorite, a texture that has previously been interpreted as characteristic of prograde metamorphic serpentinites (Wicks and Whittaker, 1977; Wicks, 1984; Viti et al., 2018). The porphyroclasts are surrounded by a matrix of chrysotile, finegrained lizardite, and polygonal and/or polyhedral serpentine (these varieties are indistinguishable with Raman; Fig. 11b; Tarling et al., 2018a). The long axes of the porphyroclasts are subparallel to the scaly foliation, and the porphyroclasts are "truncated" along their foliation-parallel margins by surfaces that are enriched in thin layers or aggregates of lizarditepolygonal serpentine (Fig. 11b). Chrysotile preferentially grows in fine-grained fibrous "beards" around the ends of the porphyroclasts (Fig. 11a, b).

\section{Discussion}

\subsection{Deformation conditions within the Livingstone Fault}

The thermodynamic stability of the serpentine group minerals is poorly constrained (Evans, 2004), making pressuretemperature conditions during deformation difficult to ascertain. The dominance of crystalline lizardite and fibrous chrysotile in both the foliated and massive shear zone serpentinite, together with the lack of an antigorite-brucite assemblage and the apparent instability of antigorite, is consistent with an estimated ambient temperature during shearing of $250-350{ }^{\circ} \mathrm{C}$ (Evans, 2004; Guillot et al., 2015). This is also broadly compatible with interpretations of prehnitepumpellyite to lower greenschist metamorphic facies in the Caples-Aspiring Terrane wall rocks (Bishop et al., 1976; Turnbull, 1980). Additionally, the general lack of incohesive brittle fault rocks in the serpentinite shear zone precludes any significant shallow, low-temperature deformation. While pressure estimates are difficult to obtain due to the inherently pressure-insensitive nature of the serpentine minerals (Guillot et al., 2015), a broad estimate of the confin- 

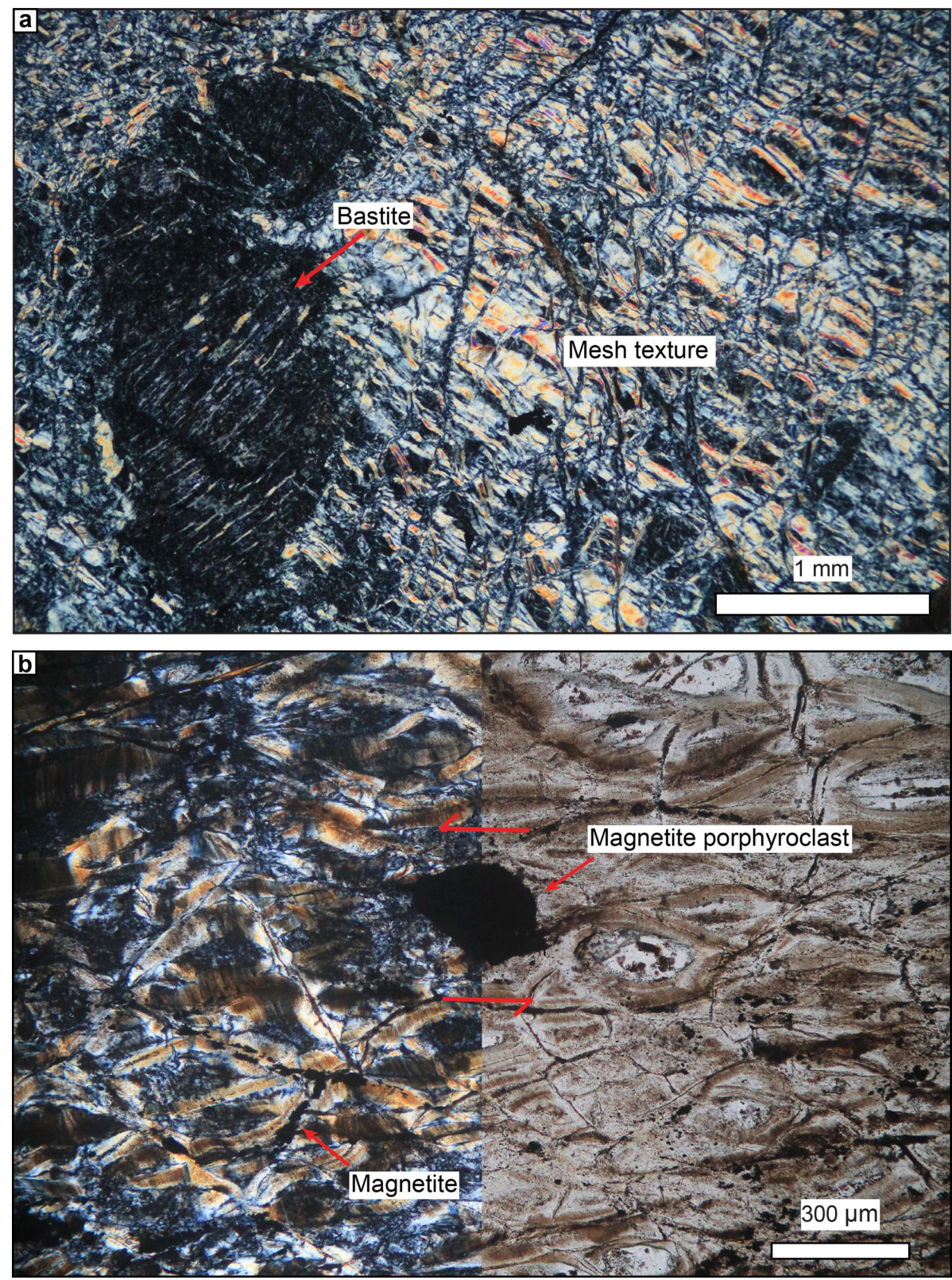

Figure 9. Serpentinite textures in pods and massive serpentinite domains. (a) Mesh-textured and bastite serpentinite from the centre of a serpentinite pod (location in Fig. 7). Optical microscope image in crossed-polarised light. (b) Sheared mesh-textured serpentinite in the initial stages of developing into "ribbon serpentinite" from within the large domain of massive serpentinite at Serpentine Saddle (location in Fig. 7) Optical microscope image in crossed-polarised light (left-hand side) and plane-polarised light (right-hand side).

ing pressure during shearing can be obtained by assuming a geothermal gradient in the range of $20-35^{\circ} \mathrm{C} \mathrm{km}^{-1}$. This geotherm is based on relatively high mantle temperatures in the Oligocene, as well as indications of a fairly thin lithosphere (Scott et al., 2014). Adopting this geotherm and a temperature of shearing in the range of $250-350^{\circ} \mathrm{C}$ suggests a confining pressure of $200-450 \mathrm{MPa}$ (roughly equivalent to $7-17 \mathrm{~km}$ of depth). Submicron Raman spectroscopy mapping (Fig. 11b) reveals evidence for early formed antigorite. In the absence of brucite, this form of serpentine is generally thought to be stable at temperatures of $>350{ }^{\circ} \mathrm{C}$ (Evans, 2004), suggesting that at least some portions of the shear zone may have experienced relatively early highertemperature deformation. One possibility is that the early higher-temperature history may relate to deformation within a shear zone associated with ophiolite obduction (Harper et al., 1996; Hermann et al., 2000). However, because evidence for this early event was largely overprinted during the development of the current steeply dipping fabrics at greenschist-facies conditions, further work will be required 

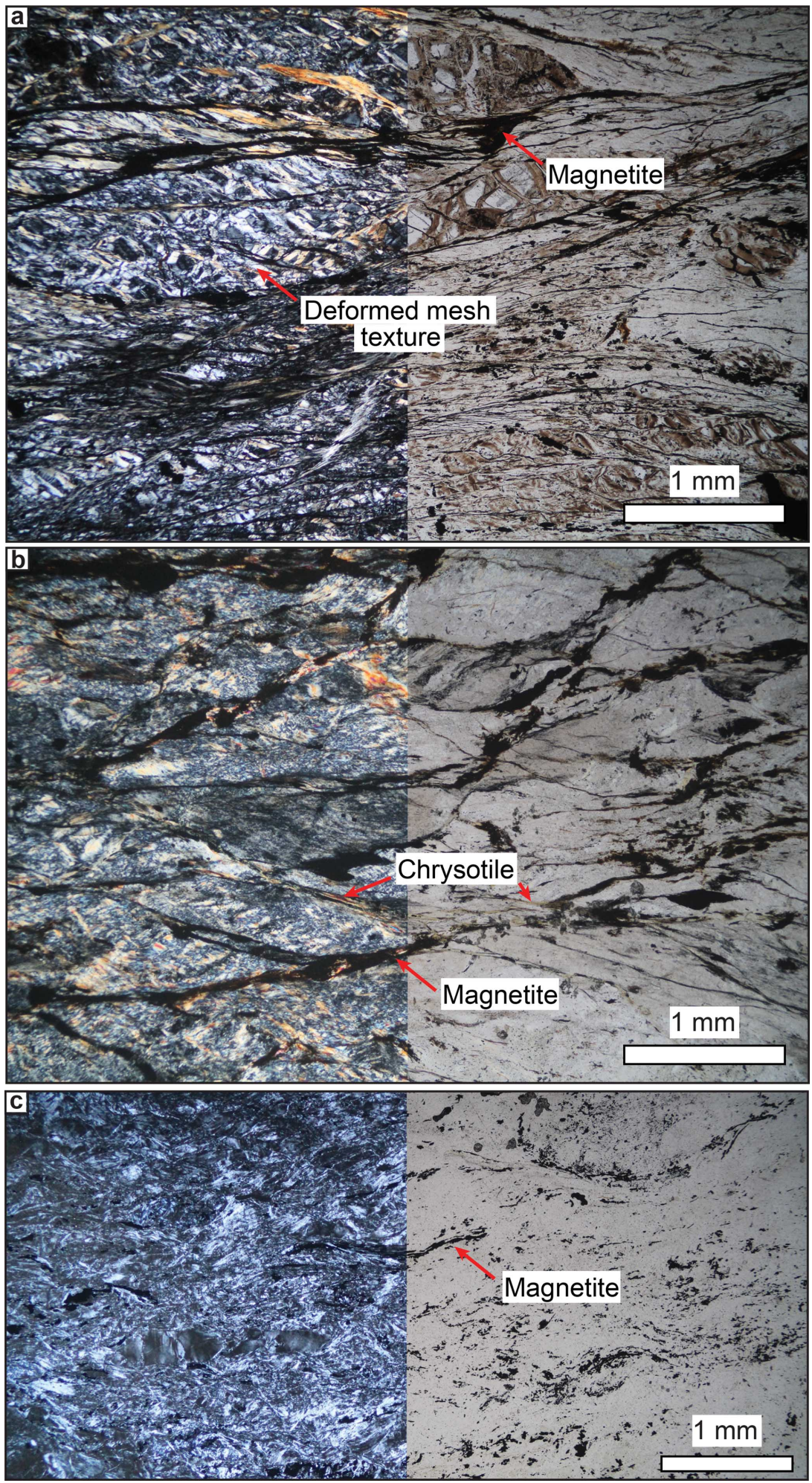

Figure 10. Evolution of serpentinite texture and mineralogy in scaly shear zone serpentinites. Each figure shows an optical microscope image in crossed-polarised light (left-hand side) and plane-polarised light (right-hand side). (a) Where the scaly foliation is relatively widely spaced, magnetite-bound phacoids preserve weakly deformed mesh-textured serpentinite composed of lizardite and chrysotile. (b) Where the scaly foliation is more closely spaced, no recognisable pseudomorphic textures are preserved. Continuous seams of magnetite outline the scaly foliation. (c) In samples of well-developed scaly serpentinite with lower proportions of magnetite, discontinuous seams of magnetite are concentrated at the boundaries of the scaly foliation, broadly defining lenticular domains of serpentinite. 


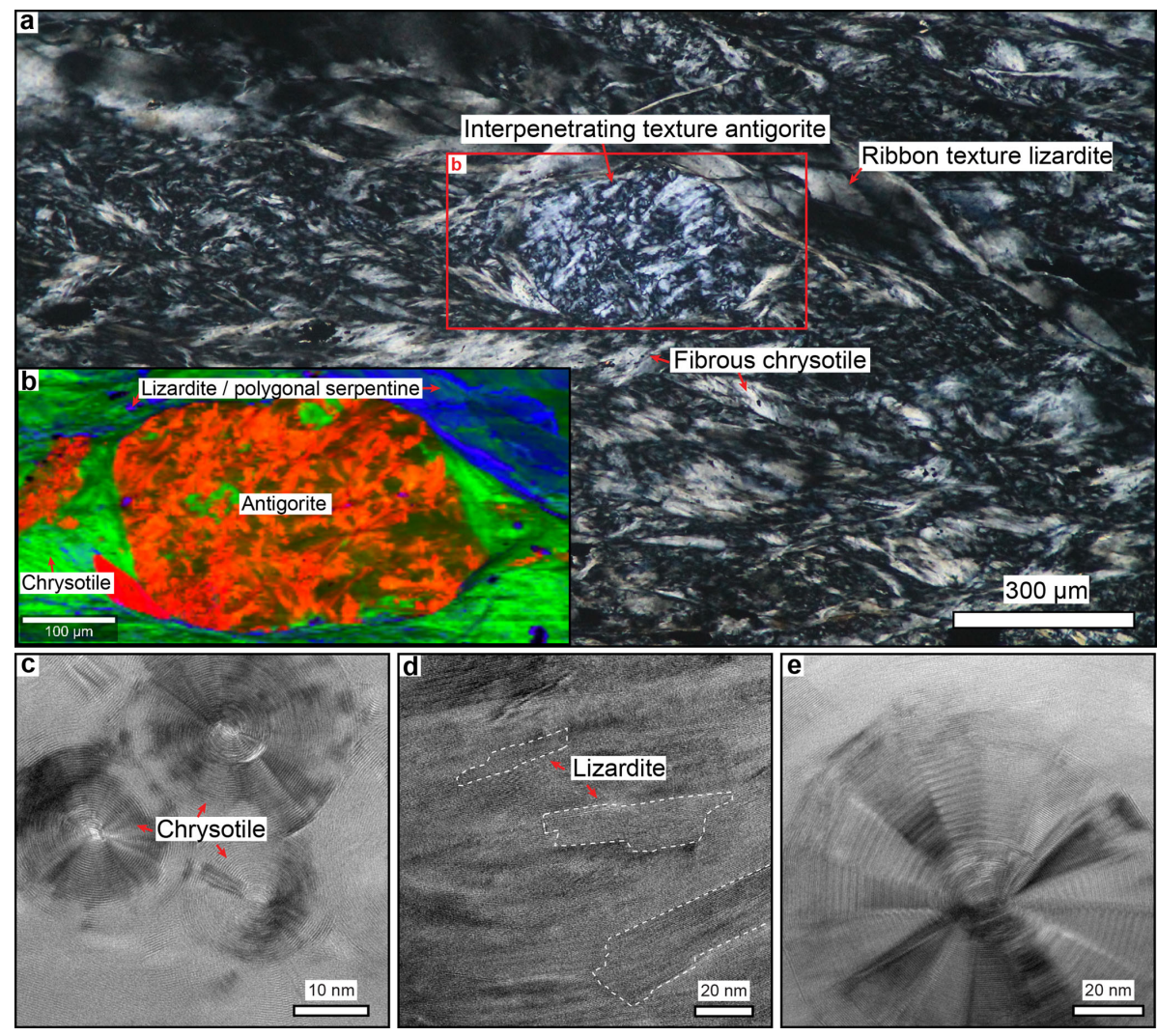

Figure 11. Raman and TEM characterisation of the scaly serpentinite fabric. (a) Representative thin section photomicrograph (crossedpolarised) of scaly serpentinite composed dominantly of chrysotile with ribbon-textured lizardite, with a porphyroclastic lens of antigorite showing an interpenetrating texture. (b) Submicron Raman spectroscopy map of the antigorite porphyroclast shown in panel (a). The map highlights a central core of antigorite (red) that is breaking down to chrysotile (green) and lizardite-polygonal serpentine (blue). The porphyroclast is elongate: margins subparallel to the scaly foliation are truncated by lizardite-polygonal serpentine-rich seams or aggregates, whereas fibrous chrysotile grows in "beards" from the ends of the porphyroclast. (c) TEM image of chrysotile-fibre cross sections. (d) TEM image of laths of lizardite. (e) TEM image of a polygonal serpentine cross section.

to properly understand the significance of the antigorite porphyroclasts preserved in the Livingstone Fault.

\subsection{A model for the internal structure and composition of plate-boundary-scale serpentinite shear zones}

Observations from 11 localities along a strike length of $140 \mathrm{~km}$ (Fig. 2) indicate that the Livingstone Fault contains a number of characteristic structural and compositional elements, which can be used to propose a general conceptual model for the structure of plate-boundary-scale serpentinite shear zones (Fig. 12)by drawing on features that have been described previously in the literature (e.g. Bebout, 2013; Hirth and Guillot, 2013; Guillot et al., 2015; Tarling et al., 2018b).

On a regional scale, the thickness of the shear varies between 5 and $480 \mathrm{~m}$ (Figs. 2, 12a). Wall rocks belonging to the DMOB are variably serpentinised for distances of up to several hundred metres from the western shear zone margin (Fig. 12a). At Serpentine Saddle, the shear zone is particu- larly thick $(420 \mathrm{~m})$ and the undeformed ultramafic portions (peridotite, serpentinised peridotite, massive serpentinite) of the DMOB wall rocks are absent (as they are at Four Brothers Pass and Beresford Pass). This suggests that the ultramafic portions of the DMOB at these three localities may have been entirely converted to scaly shear zone serpentinite (Fig. 12a). Quartzofeldspathic schists in the Caples-Aspiring wall rocks are cut by brittle faults that surround large lenses of metasomatised and fractured schist, which are ultimately plucked off and incorporated into the shear zone (Fig. 12a).

The most important structural elements and processes within the Livingstone Fault are as follows.

1. The scaly matrix serpentinite contains a pervasive foliation that wraps around pods (Fig. 12b-i). Although there is substantial local dispersion in fabric orientations, on a regional scale the fabrics consistently indicate a steep, east-side-up shear sense (Figs. 2, 7), consistent with previous work at West Burn (Craw, 1979) and in the central Southland region (Cawood, 1986, 1987). 


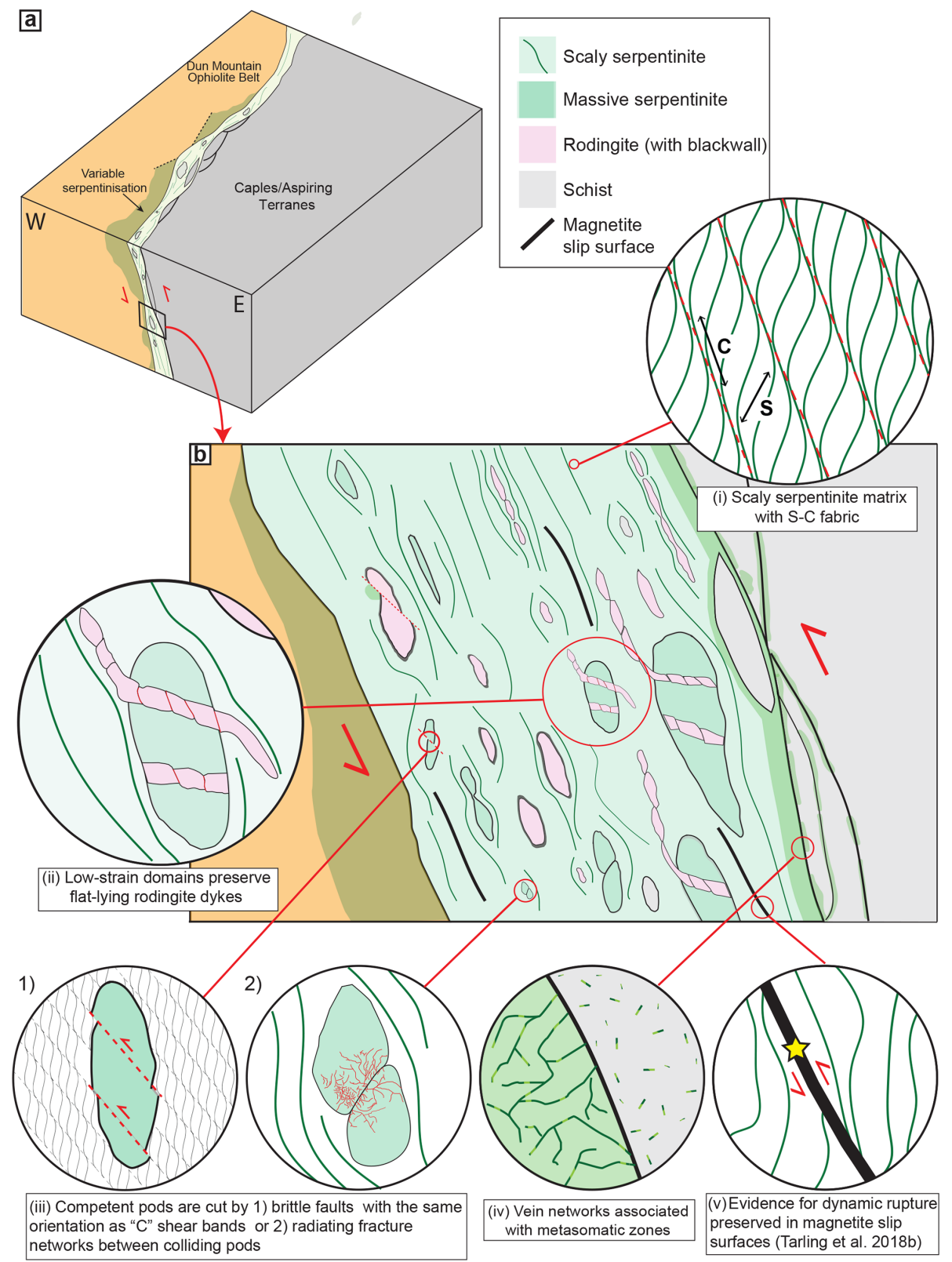

Figure 12. A conceptual model of the structure and composition of large serpentinite shear zones based on the most important structural elements and deformation processes observed in the Livingstone Fault. (a) Regional-scale characteristics. The thickness of the Livingstone Fault and the degree of serpentinisation in the DMOB wall rocks are highly variable along strike. The Caples-Aspiring wall rocks are cut by networks of brittle faults that enclose large lenses of fractured and metasomatised schist. (b) Internal structure and composition. (i) Scaly matrix serpentinite with a pervasive, steeply dipping foliation. (ii) "Low-strain domains" of massive serpentinite preserve flat-lying rodingite dykes that are sheared into the surrounding scaly matrix. (iii) Pods contain (1) brittle faults with a similar orientation to the "C" shear bands or (2) fracture networks that radiate outwards from contact regions between colliding pods. (iv) Metasomatic reactions led to the development of vein networks at the contact between serpentinite and the Caples-Aspiring Terrane. (v) Discrete magnetite-coated slip surfaces preserve evidence for dynamic rupture and coseismic dehydration of serpentinite (Tarling et al., 2018b).

2. Large domains of massive serpentinite preserve relatively intact and flat-lying rodingite dykes (Fig. 12bii). These areas are interpreted as "low-strain domains" within the shear zone and likely preserve the initial dyke configurations prior to their entrainment and boudinage within the scaly matrix.

3. Competent pods of massive serpentinite, veined serpentinite, rodingite and schist are entrained within the shear 
zone and cut by networks of brittle faults and fractures (Fig. 12b-iii). Brittle faults that cut isolated pods can have the same orientation as $\mathrm{C}$ shear bands in the surrounding scaly matrix (Fig. 12b-iii), suggesting geometric and kinematic linkage between distributed deformation in the matrix and more localised deformation in the pods. Where pods are in direct contact with each other, brittle fracture networks radiate outwards from the contact zone (Fig. 12b-iii), suggesting that local stresses in the pods were transiently elevated as they were brought into contact (Webber et al., 2018).

4. Metasomatic reactions occurred wherever serpentinites and schist are in contact, which includes the eastern boundary of the shear zone and the margins of schist pods (Fig. 12b-iv). Reactions between serpentinite and partially rodingitised gabbro-dolerite pods lead to the development of extensive metasomatic vein networks, which subsequently formed indurated pods of veined serpentinite. Additionally, reactions occurred between rodingite pods and the surrounding scaly serpentinite but only in cases in which the continuity of the enveloping blackwall rim was disrupted by brittle faulting or shearing.

5. Fault surfaces are coated by layers of magnetite, which cut across the scaly fabric (Fig. 12b-v). These fault surfaces were described by Tarling et al. (2018b), who presented evidence for extremely localised dehydration of serpentinite found as inclusions within the magnetite layers. Tarling et al. (2018b) used numerical modelling to suggest that the localised dehydration occurred by frictional heating during an ancient earthquake with a magnitude between 2.7 and 4 (Fig. 12b-v).

\subsection{Mixed rheology in plate-boundary-scale serpentinite shear zones}

The overall structure and composition of the Livingstone Fault may be representative of other large serpentinitedominated shear zones. In particular, the scale and composition of the shear zone, the "block-in-matrix" style of deformation, and the juxtaposition of ultramafic or mafic wall rocks against quartzofeldspathic wall rocks are similar to the likely characteristics of the plate-boundary-scale shear zone thought to be present along the slab-mantle interface in the shallow forearc region of subduction zones (Bebout and Barton, 1993, 2002; Bebout and Penniston-Dorland, 2016). The interpretations reached here regarding the structure of the shear zone, the potential importance of pressure-solution and the influence of metasomatic reactions are applicable over a wide range of pressure and temperature conditions (Andréani et al., 2005; Boschi et al., 2006; Auzende et al., 2006; Wassmann et al., 2011), suggesting that our observations are relevant to large serpentinite-bearing shear zones in different tectonic settings, including the slab-mantle interface.
Concentrations of magnetite along scaly foliation surfaces are interpreted to reflect the preferential dissolution of serpentine during deformation and subsequent enrichment of magnetite along dissolution surfaces (Figs. 9, 10; Rooney et al., 2018). Porphyroclasts of antigorite are elongate and show evidence for truncation by dissolution along their foliation-parallel margins, accompanied by the growth of "beards" of fibrous chrysotile (Fig. 11a, b). Additionally, abundant veins of fibrous chrysotile are found throughout the shear zone, either at the margins of individual serpentinite phacoids in the scaly fabric or as slickenfibre veins along $\mathrm{C}$ shear bands and fractures cutting resistant pods. Collectively, these microstructures indicate that dissolutionprecipitation (or pressure-solution) processes were important in forming the currently preserved scaly serpentinite matrix. This conclusion is consistent with previous work on dissolution-precipitation processes in serpentinite under greenschist- or sub-greenschist-facies conditions (Andréani et al., 2004, 2005), as well as other large-displacement fault zones with phyllosilicate-rich fault cores (Imber et al., 1997; Wintsch and Yi, 2002; Jefferies et al., 2006; Wallis et al., 2015).

Fracture networks radiating away from the contact areas between large pods suggest elevated stresses during interactions and collisions between pods (Fig. 8d, e). This could reflect a "log-jam" scenario (Fagereng and Sibson, 2010) in which transient collisions in the shear zone occur episodically as pods are brought closer together. In regions of the shear zone where the pod content is relatively high compared to the matrix, these interactions may have transiently "locked up" regions of the shear zone, allowing stresses to accumulate and brittle failure to occur within the competent pods. Additionally, the polished and cataclastic margins of rodingite pods suggest that localised brittle faulting can also occur without direct physical interactions between pods. Numerical modelling by Beall et al. (2019) shows that this can occur due to the development of elevated stresses around the margins of pods that are partially coupled to a surrounding ductiley deforming matrix.

Metasomatic reaction zones are found at the contact between schist or rodingite pods and the surrounding serpentinite. Such reactions between serpentinite and siliciccalcic lithologies that form tremolite, talc, diopside and chlorite are extensively documented in the literature (Cronshaw, 1923; Read, 1934; Nishiyama, 1990; Boschi et al., 2006; Nishiyama et al., 2017). In the Livingstone Fault, metasomatic reactions resulted in the transformation of foliated serpentinite into a highly indurated metasomatic fault rock largely consisting of networks of tremolite veins (Fig. 6). The close association of metasomatically derived vein networks with brittle, cataclastic fault surfaces suggests that metasomatic reactions and the resultant hardening effects could promote a rheological transition from distributed ductile creep towards brittle deformation and localised slip. 
Finally, we speculate that progressively concentrating magnetite along foliation surfaces and shear bands via a pressure-solution mechanism (Figs. 9,10) can ultimately lead to the development of continuous layers of magnetite. Although the magnetite layers are thin $(<1 \mathrm{~mm})$ and represent a volumetrically minor (usually $<5 \mathrm{wt} \%$, but up to $15 \mathrm{wt} \%$ ) component of the scaly serpentinite, they provide interfaces that could potentially contribute to the localisation of strain and perhaps the nucleation and/or propagation of dynamic instabilities. Evidence presented by Tarling et al. (2018b) suggests that some magnetite layers can develop into discrete fault surfaces several tens of metres long, which preserve evidence for transient dynamic rupture. The textural evolution from initially disseminated magnetite towards continuous magnetite-coated fault surfaces is a poorly constrained process, but this could be a relevant question to address using a combination of field, microstructural and experimental observations.

\section{Conclusions}

The Livingstone Fault is a plate-boundary-scale serpentinite shear zone that is tens of metres to several hundred metres wide. The bulk of the shear zone consists of a pervasive scaly fabric dominated by chrysotile and lizardite-polygonal serpentine. The scaly fabric wraps around fractured and faulted pods of massive serpentinite, rodingite and partially metasomatised quartzofeldspathic schist up to hundreds of metres long. Well-developed $\mathrm{S}-\mathrm{C}$ fabrics in the scaly serpentinite indicate an east-side-up shear sense and preserve textural evidence to suggest that pressure-solution was an important deformation mechanism during shearing. Metasomatic reactions were ubiquitous wherever serpentinite contacted schist or rodingite, forming multigenerational vein networks filled by nephritic tremolite. Based on field and microstructural observations, we present a conceptual model of the structure and composition of large serpentinite shear zones deforming at greenschist-facies conditions. The model involves bulkdistributed deformation by pressure-solution creep accompanied by localised brittle deformation within pods or along magnetite-coated fault surfaces. Metasomatic reactions can generate vein networks, leading to reaction hardening and embrittlement within metasomatised portions of the shear zone. The scale, internal structure and composition of the Livingstone Fault and its wall rocks suggest that it could provide a suitable analogue for other plate-boundary-scale serpentinite shear zones, including the serpentinite-bearing shear zone expected to occur along the slab-mantle interface in subduction zones.

Data availability. All data produced and used to write the paper are available in numerical or graphical form in the figures and/or within the paper itself.
Author contributions. MST, SAFS and JMS carried out fieldwork and performed microstructural analysis of fault rocks. MST and CV performed transmission electron microscopy. MST and JSR performed Raman analysis with input from KCG. MST wrote the paper with discussion and input from all authors. SAFS and JMS supervised the project.

Competing interests. The authors declare that they have no conflict of interest.

Acknowledgements. This work was supported by the Marsden Fund Council (project UOO1417 to Steven A. F. Smith) administered by the Royal Society Te Apārangi, with additional funding from a University of Otago research grant. Luke Easterbrook provided valuable assistance in drone imagery and photogrammetry. Chris Tulley provided field assistance on many of the field expeditions and contributed data on the Mount Raddle section collected during his BSc Hons project. Jordan Crase contributed data on the Serpentine Saddle, Cow Saddle, Fiery Col and Cosy Gully sections collected during his MSc project. We thank Marianne Negrini, Brent Pooley, Claudia Magrini and Giovanna Giorgetti for technical support. Finally, we thank Telemaco Tesei and an anonymous reviewer for their insightful reviews of the paper.

Financial support. This research has been supported by the Marsden Fund Council (grant no. UOO1417).

Review statement. This paper was edited by Cristiano Collettini and reviewed by Telemaco Tesei and one anonymous referee.

\section{References}

Adams, C., Barley, M., Fletcher, I., and Pickard, A.: Evidence from $\mathrm{U}-\mathrm{Pb}$ zircon and ${ }^{40} \mathrm{Ar} /{ }^{39} \mathrm{Ar}$ muscovite detrital mineral ages in metasandstones for movement of the Torlesse suspect terrane around the eastern margin of Gondwanaland, Terra Nova, 10, 183-189, 1998.

Adams, C., Mortimer, N., Campbell, H., and Griffin, W.: Detrital zircon ages in Buller and Takaka terranes, New Zealand: constraints on early Zealandia history, New Zeal. J. Geol. Geop., 58, 176-201, 2015.

Alexander, R. J. and Harper, G. D.: The Josephine ophiolite: an ancient analogue for slow-to intermediate-spreading oceanic ridges, Geological Society, London, Special Publications, 60, $3-$ 38, 1992.

Allibone, A. and Tulloch, A.: Early Cretaceous dextral transpressional deformation within the Median Batholith, Stewart Island, New Zealand, New Zeal. J. Geol. Geop., 51, 115-134, 2008.

Allibone, A., Jongens, R., Turnbull, I., Milan, L., Daczko, N. R., DePaoli, M., and Tulloch, A.: Plutonic rocks of Western Fiordland, New Zealand: Field relations, geochemistry, correlation, and nomenclature, New Zeal. J. Geol. Geop., 52, 379-415, 2009. 
Allmendinger, R. W., Cardozo, N., and Fisher, D. M.: Structural geology algorithms: Vectors and tensors, Cambridge University Press, Cambridge, UK, 2011.

Andréani, M., Baronnet, A., Boullier, A. M., and Gratier, J. P.: A microstructural study of a "crack-seal" type serpentine vein using SEM and TEM techniques, Eur. J. Mineral., 16, 585-595, 2004.

Andréani, M., Boullier, A. M., and Gratier, J. P.: Development of schistosity by dissolution-crystallization in a Californian serpentinite gouge, J. Struct. Geol., 27, 2256-2267, 2005.

Auzende, A.-L., Devouard, B., Guillot, S., Daniel, I., Baronnet, A., and Lardeaux, J.-M.: Serpentinites from Central Cuba: petrology and HRTEM study, Eur. J. Mineral., 14, 905-914, 2002.

Auzende, A.-L., Guillot, S., Devouard, B., and Baronnet, A.: Serpentinites in an Alpine convergent setting: effects of metamorphic grade and deformation on microstructures, Eur. J. Mineral., 18, 21-33, 2006.

Auzende, A.-L., Escartin, J., Walte, N. P., Guillot, S., Hirth, G., and Frost, D. J.: Deformation mechanisms of antigorite serpentinite at subduction zone conditions determined from experimentally and naturally deformed rocks, Earth Planet. Sc. Lett., 411, 229240, 2015.

Bach, W., Paulick, H., Garrido, C. J., Ildefonse, B., Meurer, W. P., and Humphris, S. E.: Unraveling the sequence of serpentinization reactions: Petrography, mineral chemistry, and petrophysics of serpentinites from MAR $15^{\circ} \mathrm{N}$ (ODP Leg 209, Site 1274), Geophys. Res. Lett., 33, 4-7, 2006.

Barth, N. C., Boulton, C., Carpenter, B. M., Batt, G. E., and Toy, V. G.: Slip localization on the southern Alpine Fault New Zealand, Tectonics, 32, 620-640, 2013.

Beall, A., Fagereng, A., and Ellis, S.: Strength of strained twophase mixtures: Application to rapid creep and stress amplification in subduction zone mélange, Geophys. Res. Lett., 46, 169178, 2019.

Bebout, G. E.: Metasomatism in subduction zones of subducted oceanic slabs, mantle wedges, and the slab-mantle interface, in: Metasomatism and the Chemical Transformation of Rock, pp. 289-349, Springer, Berlin, 2013.

Bebout, G. E. and Barton, M. D.: Metasomatism during subduction: products and possible paths in the Catalina Schist, California, Chem. Geol., 108, 61-92, 1993.

Bebout, G. E. and Barton, M. D.: Tectonic and metasomatic mixing in a high-T, subduction-zone melange - insights into the geochemical evolution of the me slab - mantle interface, Chem. Geol., 187, 79-106, 2002.

Bebout, G. E. and Penniston-Dorland, S. C.: Fluid and mass transfer at subduction interfaces - The field metamorphic record, Lithos, 240, 228-258, 2016.

Bellot, J.-P.: Natural deformation related to serpentinisation of an ultramafic inclusion within a continental shear zone: The key role of fluids, Tectonophysics, 449, 133-144, 2008.

Berthé, D., Choukroune, P., and Jégouzo, P.: Orthogneiss, mylonite and non coaxial deformation of granites: the example of the South Armorican Shear Zone, J. Struct. Geol., 1, 31-42, 1979.

Bishop, D., Bradshaw, J., Landis, C., and Turnbull, I.: Lithostratigraphy and structure of the Caples terrane of the Humboldt Mountains, New Zealand, New Zeal. J. Geol. Geop., 19, 827-848, 1976.

Bishop, D. G., Bradshaw, J. D., Landis, C. A.: Provisional terrane map of South Island, New Zealand, in: Tectonostratigraphic Ter- ranes of the Circum-Pacific Region. Earth Science Series, edited by: Howell, D. G., 1. Circum-Pacific Council for Energy and Mineral Resources, Houston, TX, 515-521, 1985.

Boschi, C., Früh-Green, G. L., and Escartín, J.: Occurrence and significance of serpentinite-hosted, talc- and amphibole-rich fault rocks in modern oceanic settings and ophiolite complexes: An overview, Ofioliti, 31, 129-140, 2006.

Bradshaw, J.: A review of the Median Tectonic Zone: terrane boundaries and terrane amalgamation near the Median Tectonic Line, New Zeal. J. Geol. Geop., 36, 117-125, 1993.

Brantut, N., Passelègue, F. X., Deldicque, D., Rouzaud, J. N., and Schubnel, A.: Dynamic weakening and amorphization in serpentinite during laboratory earthquakes, Geology, 44, 607-610, 2016.

Cann, J. R., Blackman, D. K., Smith, D. K., McAllister, E., Janssen, B., Mello, S., Avgerinos, E., Pascoe, A. R., and Escartin, J.: Corrugated slip surfaces formed at ridge-transform intersections on the Mid-Atlantic Ridge, Nature, 385, 329-332, 1997.

Cawood, P. A.: Stratigraphic and structural relations of the southern Dun Mountain Ophiolite Belt and enclosing strata, northwestern Southland, New Zealand, New Zeal. J. Geol. Geop., 29, 179-203, 1986.

Cawood, P. A.: Stratigraphic and structural relations of strata enclosing the Dun Mountain Ophiolite Belt in the Arthurton-Clinton region, Southland, New Zealand, New Zeal. J. Geol. Geop., 30, 19-36, 1987.

Chen, S., Pe-Piper, G., Piper, D. J., and Guo, Z.: Ophiolitic mélanges in crustal-scale fault zones: Implications for the Late Palaeozoic tectonic evolution in West Junggar, China, Tectonics, 33, 2419-2443, 2014.

Coleman, R. G.: Petrologic and geophysical nature of serpentinites, Geol. Soc. Am. B., 82, 897-918, 1971.

Coombs, D. S., Landis, C. A., Norris, R. J., Sinton, J. M., Borns, D. J., and Craw, D.: The Dun Mountain ophiolite belt, New Zealand, its tectonic setting, constitution, and origin, with special reference to the southern portion, Am. J. Sci., 276, 561-603, 1976.

Cooper, A. F. and Ireland, T. R.: The Pounamu terrane, a new Cretaceous exotic terrane within the Alpine Schist, New Zealand; tectonically emplaced, deformed and metamorphosed during collision of the LIP Hikurangi Plateau with Zealandia, Gondwana Res., 27, 1255-1269, 2015.

Cooper, R.: Early Paleozoic terranes of New Zealand, J. Roy. Soc. New Zeal., 19, 73-112, 1989.

Craw, D.: Mélanges and associated rocks, Livingstone Mountains, Southland, New Zealand, New Zeal. J. Geol. Geop., 22, 443-454, 1979.

Cronshaw, H.: The Connemara serpentine rocks, Geological Magazine, 60, 467-471, 1923.

Eccles, J., Cassidy, J., Locke, C. A., and Spörli, K. B.: Aeromagnetic imaging of the Dun Mountain Ophiolite Belt in northern New Zealand: insight into the fine structure of a major SW Pacific terrane suture, J. Geol. Soc., 162, 723-735, 2005.

Escartín, J., Mével, C., MacLeod, C. J., and McCaig, A. M.: Constraints on deformation conditions and the origin of oceanic detachments: The Mid-Atlantic Ridge core complex at $15^{\circ} 45^{\prime} \mathrm{N}$, Geochem. Geophys. Geosyst., 4, 1067 , https://doi.org/10.1029/2002GC000472, 2003. 
Evans, B. W.: The Serpentinite Multisystem Revisited: Chrysotile Is Metastable, Int. Geol. Rev., 46, 479-506, 2004.

Fagereng, Å. and MacLeod, C. J.: On Seismicity and Structural Style of Oceanic Transform Faults: A Field Geological Perspective From the Troodos Ophiolite, Cyprus, in: Transform Plate Boundaries and Fracture Zones, Elsevier, Amsterdam, the Netherlands, pp. 437-459, 2019.

Fagereng, A. and Sibson, R. H.: Mélange rheology and seismic style, Geology, 38, 751-754, 2010.

Federico, L., Crispini, L., Scambelluri, M., and Capponi, G.: Ophiolite mélange zone records exhumation in a fossil subduction channel, Geology, 35, 499-502, 2007.

Gaina, C., Müller, D. R., Royer, J.-Y., Stock, J., Hardebeck, J., and Symonds, P.: The tectonic history of the Tasman Sea: a puzzle with 13 pieces, J. Geophys. Res.-Sol. Ea., 103, 12413-12433, 1998.

Gates, A. E.: Domainal failure of serpentinite in shear zones, StateLine mafic complex, Pennsylvania, USA, J. Struct. Geol., 14, 1928, 1992.

Gray, D. R., Foster, D. A., Maas, R., Spaggiari, C. V., Gregory, R. T., Goscombe, B., and Hoffmann, K.: Continental growth and recycling by accretion of deformed turbidite fans and remnant ocean basins: Examples from Neoproterozoic and Phanerozoic orogens, Memoirs-Geological Society Of America, 200, 63-92, 2007.

Grindley, G. W.: The geology of the Eglinton valley, Southland, New Zealand Geol. Surv. B., 58, 1-68, 1958.

Guillot, S. and Hattori, K.: Serpentinites: Essential roles in geodynamics, arc volcanism, sustainable development, and the origin of life, Elements, 9, 95-98, 2013.

Guillot, S., Schwartz, S., Hattori, K., Auzende, A., and Lardeaux, J.: The Monviso ophiolitic massif (Western Alps), a section through a serpentinite subduction channel, Journal of the Virtual Explorer, 16, 17 pp., 2004.

Guillot, S., Schwartz, S., Reynard, B., Agard, P., and Prigent, C.: Tectonic significance of serpentinites, Tectonophysics, 646, 119, 2015.

Harper, G. D., Grady, K., and Coulton, A. J.: Origin of the amphibolite "sole" of the Josephine ophiolite: Emplacement of a cold ophiolite over a hot arc, Tectonics, 15, 296-313, 1996.

Hekinian, R., Bideau, D., Cannat, M., Francheteau, J., and Hébert, R.: Volcanic activity and crust-mantle exposure in the ultrafast Garrett transform fault near $13^{\circ} 28^{\prime} \mathrm{S}$ in the Pacific, Earth Planet. Sc. Lett., 108, 259-275, 1992.

Hermann, J., Müntener, O., and Scambelluri, M.: The importance of serpentinite mylonites for subduction and exhumation of oceanic crust, Tectonophysics, 327, 225-238, 2000.

Hirauchi, K. I. and Yamaguchi, H.: Unique deformation processes involving the recrystallization of chrysotile within serpentinite: Implications for aseismic slip events within subduction zones, Terra Nova, 19, 454-461, 2007.

Hirauchi, K. I., den Hartog, S. A. M., and Spiers, C. J.: Weakening of the slab-mantle wedge interface induced by metasomatic growth of talc, Geology, 41, 75-78, 2013.

Hirth, G. and Guillot, S.: Rheology and tectonic significance of serpentinite, Elements, 9, 107-113, 2013.

Hutton, C. O.: Basic and ultrabasic rocks in north-west Otago, Trans. Roy. Soc. NZ, 66, 231-254, 1936.
Imber, J., Holdsworth, R. E., Butler, C. A., and Lloyd, G. E.: Faultzone weakening processes along the reactivated Outer Hebrides Fault Zone, Scotland, J. Geol. Soc., 154, 105-109, 1997.

Jefferies, S. P., Holdsworth, R. E., Wibberley, C. A. J., Shimamoto, T., Spiers, C. J., Niemeijer, A. R., and Lloyd, G. E.: The nature and importance of phyllonite development in crustal-scale fault cores: an example from the Median Tectonic Line, Japan, J. Struct. Geol., 28, 220-235, 2006.

Jugum, D., Norris, R., and Palin, J.: Late Jurassic detrital zircons from the Haast Schist and their implications for New Zealand terrane assembly and metamorphism, New Zeal. J. Geol. Geop., 56, 223-228, 2013.

Kimbrough, D., Tulloch, A., Coombs, D., Landis, C., Johnston, M., and Mattinson, J.: Uranium-lead zircon ages from the median tectonic zone, New Zealand, New Zeal. J. Geol. Geop., 37, 393 419, 1994.

Kimbrough, D. L., Mattinson, J. M., Coombs, D. S., Landis, C. A., and Johnston, M. R.: Uranium-lead ages from the Dun Mountain ophiolite belt and Brook Street terrane, South Island, New Zealand, Geol. Soc. Am. B., 104, 429-443, 1992.

Kohli, A. H., Goldsby, D. L., Hirth, G., and Tullis, T.: Flash weakening of serpentinite at near-seismic slip rates, J. Geophys. Res.Sol. Ea., 116, 1-18, 2011.

Landis, C. and Coombs, D.: Metamorphic belts and orogenesis in southern New Zealand, Tectonophysics, 4, 501-518, 1967.

Landis, C., Campbell, H., Aslund, T., Cawood, P., Douglas, A., Kimbrough, D., Pillai, D., Raine, J., and Willsman, A.: PermianJurassic strata at Productus Creek, Southland, New Zealand: implications for terrane dynamics of the eastern Gondwanaland margin, New Zeal. J. Geol. Geop., 42, 255-278, 1999.

Lister, G. S. and Snoke, A. W.: S-C mylonites, J. Struct. Geol., 6, 617-638, 1984.

MacKinnon, T. C.: Origin of the Torlesse terrane and coeval rocks, South Island, New Zealand, Geol. Soc. Am. B., 94, 967-985, 1983.

MacPherson, E.: An outline of Late Cretaceous and Tertiary diastrophism in New Zealand, New Zealand Dept. Sci. Ind. Res., 6, 1-32, 1946.

Maltman, A., Labaume, P., and Housen, B.: Structural geology of the décollement at the toe of the barbados accretionary prism 1, Proc. ODP, Scientific Results, 156, 156, 279-292, 1997.

Maltman, A. J.: Serpentinite textures in Anglesey, North Wales, United Kingdom, Geol. Soc. Am. B., 89, 972-980, 1978.

Mellini, M., Rumori, C., and Viti, C.: Hydrothermally reset magmatic spinels in retrograde serpentinites: formation of "ferritchromit" rims and chlorite aureoles, Contrib. Mineral. Petr., 149, 266-275, 2005.

Melosh, B. L.: Fault initiation in serpentinite, Geochem. Geophys. Geosyst., https://doi.org/10.1029/2018GC008092, 2019.

Melson, W. G. and Thompson, G.: Petrology of a transform fault zone and adjacent ridge segments, Phil. Trans. R. Soc. Lond. A, 268, 423-441, 1971.

Moore, D. E. and Lockner, D. A.: Chemical controls on fault behavior: Weakening of serpentinite sheared against quartz-bearing rocks and its significance for fault creep in the San Andreas system, J. Geophys. Res.-Sol. Ea., 118, 2558-2570, 2013.

Moore, D. E. and Rymer, M. J.: Talc-bearing serpentinite and the creeping section of the San Andreas fault, Nature, 448, 795-797, 2007. 
Moore, D. E., Lockner, D., Summers, R., Shengli, M., and Byerlee, J.: Strength of chrysotile-serpentinite gouge under hydrothermal conditions: Can it explain a weak San Andreas Fault?, Geology, 24, 1041-1044, 1996.

Moore, D. E., Lockner, D. A., Tanaka, H., and Iwata, K.: The coefficient of friction of Chrysotile gouge at seismogenic depths, Int. Geol. Rev., 46, 385-398, 2004.

Moore, D. E., McLaughlin, R. J., and Lienkaemper, J. J.: Serpentinite-Rich Gouge in a Creeping Segment of the Bartlett Springs Fault, Northern California: Comparison With SAFOD and Implications for Seismic Hazard, Tectonics, 37, 4515-4534, 2018.

Moore, J. C.: Structural fabric in Deep Sea Drilling Project cores from forearcs, vol. 166, Geol. Soc. Am., 1986.

Mortimer, N.: New Zealand's geological foundations, Gondwana Res., 7, 261-272, 2004.

Mortimer, N., Tulloch, A. J., Spark, R. N., Walker, N. W., Ladley, E., Allibone, A., and Kimbrough, D. L.: Overview of the Median Batholith, New Zealand: a new interpretation of the geology of the Median Tectonic Zone and adjacent rocks, J. Afr. Earth Sci., 29, 257-268, 1999.

Mortimer, N., Davey, F. J., Melhuish, A., Yu, J., and Godfrey, N. J.: Geological interpretation of a deep seismic reflection profile across the Eastern Province and Median Batholith, New Zealand: Crustal architecture of an extended Phanerozoic convergent orogen, New Zeal. J. Geol. Geop., 45, 349-363, 2002.

Muir, R., Ireland, T., Weaver, S., and Bradshaw, J.: Ion microprobe dating of Paleozoic granitoids: Devonian magmatism in New Zealand and correlations with Australia and Antarctica, Chem. Geol., 127, 191-210, 1996.

Nicolas, A., Girardeau, J., Marcoux, J., Dupre, B., Xibin, W., Yougong, C., Haixiang, Z., and Xuchang, X.: The Xigaze ophiolite (Tibet): a peculiar oceanic lithosphere, Nature, 294, 414-417, 1981.

Nishiyama, T.: $\mathrm{CO}_{2}$ metasomatism of a metabasite block in a serpentine melange from the Nishisonogi metamorphic rocks, Southwest Japan, Contrib. Mineral. Petr., 104, 35-46, 1990.

Nishiyama, T., Shiosaki, C. Y., Mori, Y., and Shigeno, M.: Interplay of irreversible reactions and deformation: a case of hydrofracturing in the rodingite-serpentinite system, Progress in Earth and Planetary Science, 4, 1, 2017.

Norrell, G. T., Teixell, A., and Harper, G. D.: Microstructure of serpentinite mylonites from the Josephine ophiolite and serpentinization in retrogressive shear zones, California, Geol. Soc. Am. B., 101, 673-682, 1989.

O'Brien, J. and Rodgers, K.: Alpine-type serpentinites from the Auckland Province-I. The Wairere serpentinite, J. Roy. Soc. New Zeal., 3, 169-190, 1973.

O'Hanley, D. S. and Dyar, M. D.: The composition of lizardite $1 T$ and the formation of magnetite in serpentinites, American Mineralogist, 78, 391-404, 1993.

Passchier, C. W. and Trouw, R. A.: Microtectonics, vol. 1, Springer Science \& Business Media, Berlin, 2005.

Poulet, T., Veveakis, E., Regenauer-Lieb, K., and Yuen, D. A.: Thermo-poro-mechanics of chemically active creeping faults: 3 . The role of serpentinite in episodic tremor and slip sequences, and transition to chaos, J. Geophys. Res.-Sol. Ea., 119, 46064625, 2014.
Read, H. H.: On zoned associations of antigorite, talc, actinolite, chlorite, and biotite in Unst, Shetland Islands, The Mineralogical Magazine and Journal of The Mineralogical Society, 23, 519540, 1934.

Reinen, L. A., Weeks, J. D., and Tullis, T. E.: The frictional behavior of serpentinite: Implications for aseismic creep on shallow crustal faults, Geophys. Res. Lett., 18, 1921-1924, 1991.

Reinen, L. A., Weeks, J. D., and Tullis, T. E.: The frictional behavior of lizardite and antigorite serpentinites: Experiments, constitutive models, and implications for natural faults, Pure Appl. Geophys., 143, 317-358, 1994.

Reynard, B.: Serpentine in active subduction zones, Lithos, 178, 171-185, 2013.

Rooney, J. S., Tarling, M. S., Smith, S. A., and Gordon, K. C.: Submicron Raman spectroscopy mapping of serpentinite fault rocks, J. Raman Spectrosc., 49, 279-286, 2018.

Saleeby, J. B.: Tectonic significance of serpentinite mobility and ophiolitic melange, Geological Society of America, Special Paper, 198, 153-168, 1984.

Sano, S., Tazaki, K., Koide, Y., Nagao, T., Watanabe, T., and Kawachi, Y.: Geochemistry of dike rocks in Dun mountain ophiolite, Nelson, New Zealand, New Zeal. J. Geol. Geop., 40, 127136, 1997.

Schneider, C. A., Rasband, W. S., and Eliceiri, K. W.: NIH Image to ImageJ: 25 years of image analysis, Nat. Methods, 9, 671-675, 2012.

Scott, J. M.: A review of the location and significance of the boundary between the Western Province and Eastern Province, New Zealand, New Zeal. J. Geol. Geop., 56, 276-293, 2013.

Scott, J. M., Waight, T. E., Van der Meer, Q. H. A., Palin, J. M., Cooper, A. F., and Münker, C.: Metasomatized ancient lithospheric mantle beneath the young Zealandia microcontinent and its role in HIMU-like intraplate magmatism, Geochem. Geophys. Geosyst., 15, 3477-3501, 2014.

Shackleton, R., Ries, A., Graham, R., and Fitches, W.: Late Precambrian ophiolitic melange in the Eastern Desert of Egypt, Nature, 285, 472-474, 1980.

Singleton, J. S. and Cloos, M.: Kinematic analysis of melange fabrics in the Franciscan Complex near San Simeon, California: Evidence for sinistral slip on the Nacimiento fault zone?, Lithosphere, 5, 179-188, 2012.

Sinton, J. M.: Equilibration history of the basel alpine-type peridotite, Red Mountain, New Zealand, J. Petrol., 18, 216-246, 1977.

Skjerlie, K. and Furnes, H.: Evidence for a fossil transform fault in the Solund-Stavfjord ophiolite complex: West Norwegian Caledonides, Tectonics, 9, 1631-1648, 1990.

Soda, Y. and Takagi, H.: Sequential deformation from serpentinite mylonite to metasomatic rocks along the Sashu Fault, SW Japan, J. Struct. Geol., 32, 792-802, 2010.

Stewart, E., Lamb, W., Newman, J., and Tikoff, B.: The petrological and geochemical evolution of early forearc mantle lithosphere: an example from the Red Hills Ultramafic Massif, New Zealand, J. Petrol., 57, 751-776, 2016.

Strating, E. H. H. and Vissers, R. L.: Structures in natural serpentinite gouges, J. Struct. Geol., 16, 1205-1215, 1994.

Sutherland, R., Davey, F., and Beavan, J.: Plate boundary deformation in South Island, New Zealand, is related to inherited lithospheric structure, Earth Planet. Sc. Lett., 177, 141-151, 2000. 
Tarling, M. S., Gordon, K. C., Rooney, J. S., Viti, C., and Smith, S. A. F.: Distinguishing the Raman spectrum of polygonal serpentine, J. Raman Spectros., 49, 1978-1984, 2018a.

Tarling, M. S., Smith, S. A., Viti, C., and Scott, J. M.: Dynamic earthquake rupture preserved in a creeping serpentinite shear zone, Nature Comm., 9, 3552, 2018 b.

Tesei, T., Harbord, C. W. A., De Paola, N., Collettini, C., and Viti, C.: Friction of Mineralogically Controlled Serpentinites and Implications for Fault Weakness, J. Geophys. Res.-Sol. Ea., 123, 6976-6991, 2018.

Tulloch, A., Ramezani, J., Kimbrough, D., Faure, K., and Allibone, A.: U-Pb geochronology of mid-Paleozoic plutonism in western New Zealand: Implications for S-type granite generation and growth of the east Gondwana margin, Geol. Soc. Am. B., 121, 1236-1261, 2009.

Turnbull, I. M.: Structure and interpretation of the Caples terrane of the Thomson Mountains, northern Southland, New Zealand, New Zeal. J. Geol. Geop., 23, 43-62, 1980.

Twiss, R. J. and Gefell, M. J.: Curved slickenfibers: a new brittle shear sense indicator with application to a sheared serpentinite, J. Struct. Geol., 12, 471-481, 1990.

Vannucchi, P.: Scaly fabric and slip within fault zones, Geosphere, 15, 342-356, 2019.

Vannucchi, P., Maltman, A., Bettelli, G., and Clennell, B.: On the nature of scaly fabric and scaly clay, J. Struct. Geol., 25, 673688, 2003.

Viti, C. and Mellini, M.: Contrasting chemical compositions in associated lizardite and chrysotile in veins from Elba, Italy, Eur. J. Mineral., 9, 585-596, 1997.

Viti, C. and Mellini, M.: Mesh textures and bastites in the Elba retrograde serpentinites, Eur. J. Mineral, 10, 1341-1359, 1998.
Viti, C., Collettini, C., Tesei, T., Tarling, M., and Smith, S.: Deformation Processes, Textural Evolution and Weakening in Retrograde Serpentinites, Minerals, 8, 241, 2018.

Wallis, D., Lloyd, G. E., Phillips, R. J., Parsons, A. J., and Walshaw, R. D.: Low effective fault strength due to frictional-viscous flow in phyllonites, Karakoram Fault Zone, NW India, J. Struct. Geol., 77, 45-61, 2015.

Wassmann, S., Stöckhert, B., and Trepmann, C. A.: Dissolution precipitation creep versus crystalline plasticity in high-pressure metamorphic serpentinites, Geological Society, London, Special Publications, 360, 129-149, 2011.

Webber, S., Ellis, S., and Fagereng, Å.: "Virtual shear box" experiments of stress and slip cycling within a subduction interface mélange, Earth Planet. Sc. Lett., 488, 27-35, 2018.

Wellman, H.: Data for the study of recent and late Pleistocene faulting in the South Island of New Zealand, New Zealand Journal of Science and Technology, 34, 270-288, 1953.

Wicks, F. J.: Deformation Histories As Recorded By Serpentinites - II. Deformation During and After Serpentinization, Can. Mineral., 22, 197-203, 1984.

Wicks, F. J. and Whittaker, E. J. W.: Serpentine textures and serpentinization, Can. Mineral., 15, 459-488, 1977.

Williams, A. J.: Foliation development in serpentinites, Glenrock, New South Wales, Tectonophysics, 58, 81-95, 1979.

Wintsch, R. P. and Yi, K.: Dissolution and replacement creep: a significant deformation mechanism in mid-crustal rocks, J. Struct. Geol., 24, 1179-1193, 2002.

Wood, B. L.: The geology of the Gore Subdivision, New Zealand Geol. Surv., 53, 1-128, 1956. 